NBER WORKING PAPER SERIES

\title{
DO EMPLOYEES BENEFIT FROM WORKER REPRESENTATION ON CORPORATE BOARDS?
}

\author{
Christine Blandhol \\ Magne Mogstad \\ Peter Nilsson \\ Ola L. Vestad \\ Working Paper 28269 \\ http://www.nber.org/papers/w28269
NATIONAL BUREAU OF ECONOMIC RESEARCH 1050 Massachusetts Avenue
Cambridge, MA 02138 \\ December 2020, Revised August 2021
}

The project received financial support from the Norwegian Research Council (grant number 275123). We are grateful for useful comments from seminar participants at the CESifo, the University of Oslo, the University of Essex, and the Research Institute of Industrial Economics (IFN). The views expressed herein are those of the authors and do not necessarily reflect the views of the National Bureau of Economic Research.

NBER working papers are circulated for discussion and comment purposes. They have not been peer-reviewed or been subject to the review by the NBER Board of Directors that accompanies official NBER publications.

(C) 2020 by Christine Blandhol, Magne Mogstad, Peter Nilsson, and Ola L. Vestad. All rights reserved. Short sections of text, not to exceed two paragraphs, may be quoted without explicit permission provided that full credit, including (C) notice, is given to the source. 
Do Employees Benefit from Worker Representation on Corporate Boards?

Christine Blandhol, Magne Mogstad, Peter Nilsson, and Ola L. Vestad

NBER Working Paper No. 28269

December 2020, Revised August 2021

JEL No. G34,G38,J31,J54,J58

\begin{abstract}
Do employees benefit from worker representation on corporate boards? Economists and policymakers are keenly interested in this question - especially lately, as worker representation is widely promoted as an important way to ensure the interests and views of the workers. To investigate this question, we apply a variety of research designs to administrative data from Norway. We find that a worker is paid more and faces less earnings risk if she gets a job in a firm with worker representation on the corporate board. However, these gains in wages and declines in earnings risk are not caused by worker representation per se. Instead, the wage premium and reduced earnings risk reflect that firms with worker representation are likely to be larger and unionized, and that larger and unionized firms tend to both pay a premium and provide better insurance to workers against fluctuations in firm performance. Conditional on the firm's size and unionization rate, worker representation has little if any effect. Taken together, these findings suggest that while workers may indeed benefit from being employed in firms with worker representation, they would not benefit from legislation mandating worker representation on corporate boards.
\end{abstract}

Christine Blandhol

Department of Economics

Princeton University

20 Washington Rd.

Princeton, NJ 08544

christine.blandhol@gmail.com

Magne Mogstad

Department of Economics

University of Chicago

1126 East 59th Street

Chicago, IL 60637

and NBER

magne.mogstad@gmail.com

\author{
Peter Nilsson \\ IIES, Stockholm University \\ Frescativägen \\ 11419 Stockholm \\ Sweden \\ Peter.nilsson@iies.su.se \\ Ola L. Vestad \\ Research Department \\ Statistics Norway \\ Postboks 2633 St. Hanshaugen \\ 0131 Oslo \\ Norway \\ ola.vestad@ssb.no
}




\section{Introduction}

Corporations are made up of multiple stakeholders, including workers, managers, and shareholders. The rights and interests of these stakeholders vary markedly across western market economies. On the one hand, both the US and the UK follow a corporate governance system of shareholder primacy. In it, it is the shareholders, and the shareholders alone, that elect the corporate board, which directly or indirectly manages the corporation on behalf of the shareholders. On the other hand, many European countries follow a shared governance system that grants workers formal authority in the corporate decision-making, often in the form of worker representation on corporate boards. As many economies have seen significant declines in the labor share of income, worker representation on corporate boards has gained popularity as a way to ensure the interests and views of the workers. For example, recent polls suggest that a majority of American voters want workers to hold seats on corporate boards, ${ }^{1}$ and leading politicians both in the US and the UK are advocating a system of shared governance. ${ }^{2}$ Yet, there is limited scientific evidence on how such a shared governance system actually affects firms and workers.

In this paper, we contribute to an emerging empirical literature that tries to understand whether, to what extent, and why employees benefit from worker representation on corporate boards (see e.g. Gorton and Schmid, 2004; Jäger, Schoefer and Heining (2021)). We find that a worker is paid more and faces less earnings risk if she gets a job in a firm with worker representation on the corporate board. However, these gains in wages and declines in earnings risk are not caused by worker representation per se. Instead, the wage premium and reduced earnings risk reflect that firms with worker representation are likely to be larger and unionized, and that larger and unionized firms tend to both pay a premium and better insure workers against fluctuations in firm performance. Conditional on the firm's size and unionization rate, worker representation has little if any effect. Taken together, these findings suggest that while workers may indeed benefit from being employed in firms with worker representation, they would not benefit from legislation mandating worker representation on corporate boards.

We reach these conclusions in the context of Norway, drawing on two strengths of the Norwegian environment. First, by linking several administrative data sources we are able to construct a matched panel dataset of all workers, firms, and corporate boards for the period 2004-2014. This panel data allows us to measure the worker representation status of firms and to follow workers over time, even if they switch between firms. Second, the rich data combined with institutional features allow us to use a variety of research designs. This includes a mover design comparing

\footnotetext{
${ }^{1}$ See https://www.vox.com/2018/4/6/17086720/poll-corporate-board-democracy-worker-councilcodetermination-union-labor.

${ }^{2} \mathrm{~A}$ prominent example from the US is Senator Elizabeth Warren, who proposed a federal bill in 2018 that would give workers in large corporations the right to elect two fifths of all board seats; https://www.vox.com/2018/8/15/17683022/elizabeth-warren-accountable-capitalism-corporations. Worker representation has also been high on the political agenda in the UK, with Theresa May pledging to have workers represented on corporate boards in her campaign for the 2016 Conservative Party leadership election; https://www.theguardian.com/politics/nils-pratley-on-finance/2016/jul/11/theresa-may-plan-workersboardroom-reform-extraordinary-tories.
} 
different groups of workers before and after a switch between firms with different representation status; a difference-in-differences analysis studying changes in worker compensation in response to idiosyncratic shocks to firm performance; an event study analysis exploiting differences in the timing of adoption of worker representation; and a regression discontinuity design taking advantage of a law regulating the rights to worker representation as a discontinuous function of firm size. ${ }^{3}$

We apply this variety of research designs to draw causal inference about two related yet distinct sets of parameters. The first set captures the causal effects of working in a firm with worker representation on the corporate board. These effects are relevant to understand how much where you work determine what you earn and the earnings risk you face. To estimate the wage effects of working in a firm with worker representation, we compare workers switching between firms with different representation status to their co-workers switching between firms with the same representation status. On average, we find that workers moving into firms with worker representation experience a four percent increase in wages, compared with their former co-workers moving between firms without representation. Conversely, workers moving out of firms with worker representation experience, on average, a three percent drop in wages, compared with their former co-workers moving between firms with representation. The wages of workers in firms with worker representation are not only higher on average, but they are also better insured against fluctuations in firm performance. Controlling for time-invariant worker and firm heterogeneity, we estimate a significantly lower pass through of idiosyncratic firm shocks to incumbent workers' wages in firms with representation. In response to a 10 percent fall in the value added of a firm, the wages of workers decrease by 0.9 percent in firms without worker representation, while the wages of workers only decrease by 0.2 percent in firms with worker representation.

The second set of parameters captures the causal effects of adopting worker representation on the corporate board of a given firm. These effects are relevant for assessing the impacts of a policy that would introduce or remove worker representation on corporate boards. Using the regulation governing workers' rights to representation, we find no evidence of a discontinuity in wages at the firm size cut-off. By contrast, there is a large jump in the share of firms with worker representation at the firm size cut-off. These findings are not likely to be driven by sorting of firms or workers; both the density of workers and the distribution of pre-determined characteristics are smooth around the cut-off. To complement the regression discontinuity results, we exploit differences in the timing of adoption of worker representation in an event study analysis. We find no evidence of any significant change in incumbent workers' compensation in the years following adoption, relative to the control group comprised of workers in firms adopting worker representation later in the sample period. Furthermore, we find that firms are not significantly affected by the adoption of worker

\footnotetext{
${ }^{3}$ As discussed in more detail later, one potential threat to the validity of our regression discontinuity design is manipulation of the assignment variable. If such manipulation occurs, we would expect to see sharp discontinuities around the firm size cut-off - in the firm size distribution or in pre-determined characteristics. Empirically, we find no evidence of such manipulation. This could either be because firms are not able to manipulate (for example because of worker mobility and churning) or because worker representation matters little if anything for firm performance. Consistent with the latter explanation, we find that firms are not significantly affected by the adoption of worker representation on the corporate board.
} 
representation on the corporate board. We consider a wide range of firm outcomes and find that few if any change as a result of adoption. This conclusion holds true both when we use the regression discontinuity design and when we use the event study framework.

The estimates of these two sets of parameters suggest that while employees do benefit from working in a firm with worker representation, the gains are not driven by worker representation per se, but rather by other factors that are correlated with both worker representation and worker compensation. We develop this argument in several ways. We first show that firms with worker representation stand out as considerably larger and more unionized than firms without representation. Returning to our analysis of job switchers, we next estimate sizable wage premia associated with working in larger or more unionized firms. Furthermore, we show that workers in larger or more unionized firms are better insured against fluctuations in firm performance. Lastly, we demonstrate that the gains from working in a firm with worker representation disappear once one accounts for differences in firm size and the share of unionized workers. One possible explanation for this absence of significant effects of adopting worker representation on the corporate board is that minority positions on corporate boards have little influence on the overall strategy and pay schemes of the firm. This would be consistent with the findings of Bertrand et al. (2019), who document that gender quotas on corporate boards had very little discernible impact on women in business beyond its direct effect on the women who made it into boardrooms.

Our paper contributes to a growing empirical literature on the role of the boards of directors in corporate governance. Adams et al. (2010) review the literature, emphasizing measurement and identification challenges that have made it difficult to draw causal inferences in this setting. Several recent studies have made important progress to overcome these challenges (see e.g. Ahern and Dittmar, 2012; Black and Kim, 2012; Matsa and Miller, 2013; Bertrand et al., 2019). The closest studies to our work are concerned with how firm and worker outcomes are influenced by worker representation on corporate boards. In particular, a series of papers have studied worker representation on the supervisory boards of German corporations, using (changes in) the regulations governing workers' right to representation to draw causal inferences. Gorton and Schmid (2004) exploit a discontinuity in the rights to worker representation, with workers' share of the seats on the supervisory board increasing from one third to one half at a firm size threshold of 2,000 employees. ${ }^{4}$ Consistent with our results, they find that increasing the share of workers on the supervisory board from one third to one half does not have a significant effect on the average wage at the firm-level. Jäger, Schoefer and Heining (2021) study the effects of a reform that abolished the rights to worker representation for newly incorporated firms while leaving older firms unaffected. They find that worker representation on supervisory boards increase investment and capital formation, while wages are unaffected.

We complement the results from the German setting in several ways. Our paper differs in

\footnotetext{
${ }^{4}$ More recent contributions using the same firm size threshold for identification include Lin et al. (2018), Kim et al. (2018), and Redeker (2019). These studies extend the work of Gorton and Schmid (2004) in several ways, including studying different outcomes. For instance, Kim et al. (2018) study the impacts of negative industry-level shocks on layoffs to assess the influence of worker representation on risk sharing between employers and employees.
} 
that we distinguish between two distinct causal parameters that are both informative about the roles of worker representation. ${ }^{5}$ While previous papers have focused on estimating the causal impacts of introducing or removing worker representation on the corporate board of a given firm, we complement the existing literature by presenting new evidence on the causal impacts of working in a firm with worker representation. The latter is the relevant parameter for understanding the sources of inequality in wages across observationally equivalent workers. Our results point to a significant but modest effect on average wages of working in a firm with worker representation, and a noticeable difference in the wage insurance provided by firms with and without representation. By comparison, our analyses of adopting worker representation on the corporate board of a given firm suggest that it has little if any impact on the wages of workers, consistent with the findings from the German setting. Our paper also contributes by trying to explain why there are significant effects of working in a firm with worker representation, but no effects of worker representation per se. Our findings point to firm size and the share of unionized workers as important drivers of the differences in compensation across workers in firms with and without worker representation.

When comparing our results to those reported in previous studies, it is useful to observe that Germany and Norway differ in the system for worker representation. Germany has a two-tiered board system, with both a supervisory board and an executive board. Norway, on the other hand, has the same system as in the US, the UK, and several other European countries, with a single-tiered board of directors. Worker representatives on the executive boards of Norwegian corporations are likely to be more directly involved in day-to-day operations than those on the supervisory boards of German corporations. Despite the differences in institutions, our estimates of the wage effects of adopting worker representation are in line with the results from the German setting. This finding suggests the conclusion about the absence of wage impacts of worker representation generalizes across shared governance systems that differ markedly in the degree to which workers are given authority in the corporate decision-making. ${ }^{6}$

Our paper also contributes to a large literature on the role of labor market institutions in the determination of wages. One set of studies investigates the relationship between unions and (inequality in) wages (e.g. Lemieux, 1993; Card, 1996; DiNardo et al., 1996). Another set of studies estimates firm-level heterogeneity in the pass through of changes in firm performance to wages, interpreting the estimates as informative about the degree of wage insurance (see e.g. Guiso et al., 2005; Juhn et al., 2018; Balke and Lamadon, 2020). Our study contributes to this literature by estimating how wages and earnings risk vary across firms according to worker representation, firm

\footnotetext{
${ }^{5}$ Research in other areas, such as the literature on unions, has also emphasized the distinction between these two sets of parameters. For instance, Lemieux (1993) uses job movers to estimate effects of working in union versus non-union jobs on the level and variance of wages, while DiNardo and Lee (2004) use a regression discontinuity design to estimate the impacts of unionization on business survival, employment, output, productivity, and wages.

${ }^{6}$ Recent work by Harju et al. (2021) examines the introduction of formal information-sharing institutions in Finland. This includes worker representation on corporate boards but also worker representation on management boards and other forms of representation, including representation on advisory boards and regular meetings between top-level management and worker representatives. They find no effects of formal information-sharing institutions on voluntary job separations, and at most small positive effects on other measures of job quality (job security, health, subjective job quality, and wages).
} 
size, and unionization.

The remainder of the paper proceeds as follows. Section 2 presents our data and describes our sample selection. Section 3 describes key features of wage setting and worker representation in Norway, and presents descriptive evidence. Section 4 estimates the causal effects of working in a firm with worker representation. Section 5 estimates the causal effects of worker representation on wages using both a regression discontinuity design and an event study analysis around the adoption of worker representation. Section 6 explores alternative explanations for the differences in wage setting between firms with and without representation and describes potential mechanisms. The final section concludes.

\section{Data}

Below we describe our data and sample selection. Details about the data sources and each of the variables are given in Appendix Section A.

\subsection{Data sources}

Our empirical analyses are based on several administrative data sources that we are able to link together using unique identifiers for firms and workers. This results in a matched panel dataset with detailed information on the characteristics and outcomes of Norwegian workers, firms, and corporate boards for the period 2004-2014.

Our main source of data on employment and workers' compensation is a matched employeremployee panel data set, consisting of annual tax records of the universe of workers that are matched to non-pecuniary information about employment from the Norwegian Labor and Welfare Administration. This register is used in the administration of sickness benefits and therefore subject to extensive quality controls. The dataset includes information on total earnings, contracted hours, and the number of days worked at each job. Earnings include fixed salary, bonus, overtime, and vacation and severance pay, but exclude sickness benefits. We construct hourly wages using annual earnings and contracted hours, adjusting for the number of days worked.

Our firm data draws on several administrative registers maintained by the Brønnøysund Register Center. We obtain information from firms' income statements and balance sheets, including revenue and cost of inputs, from the Register of Company Accounts. This register covers the universe of limited liability firms - the most common legal entity type of firms and also the population affected by the regulation governing the rights to worker representation. In our analysis, we define value added as revenue net of cost of inputs. We merge the income statement and balance sheet data with information on the industry and geographic location of each firm from the Central Register of Establishments and Enterprises.

Lastly, starting in 2004 we are able to merge in administrative data on the composition of boards of directors from the Register of Legal Entities. Firms are required by law to report the identity and the role of each director, including whether each director was elected by and among 
the employees or by the shareholders. This allows us to observe the worker representation status of each firm from 2004 onward, and to measure adoption of worker representation for firms adopting worker representation on the corporate board for the first time.

\subsection{Sample selection and summary statistics}

We construct our baseline sample using workers between 25 and 60 years old and define the highestpaying job in each year as the worker's main job. We exclude firms operating in industries which are exempt from the regulation governing worker representation ( $1.5 \%$ of firms, $6.6 \%$ of workers), and we also drop a small number of observations with missing value added, industry, or region (5\% of firms, $5 \%$ of workers). With these restrictions, our baseline sample consists of about 1.5 million workers and 128 thousand firms.

We use a variety of research designs, each with its own subsample. Table 1 summarizes the sample restrictions and reports the number of workers and firms for each subsample. The first subsample, which we refer to as the movers sample, restricts the full sample to workers observed transitioning between firms with different representation status (treatment group workers) and their co-workers switching between firms with the same representation status (control group workers). To make sure that the treatment and control group workers are moving from similar types of firms, we restrict the sample to firms with at least one treatment and one control group worker who are switching jobs in the same year. The worker representation status of each firm is measured two years before the worker switches to another firm. We focus on the first full-time job-to-job transition for each worker and consequently exclude moves where the individual is observed claiming unemployment insurance benefits in the year of the move.

The second subsample, which we refer to as the stayers sample, restricts the full sample to workers observed with the same firm for at least six consecutive years. This restriction ensures that changes in the compensation of workers in response to changes in firm performance are not driven by selective attrition of low- or high-wage workers.

The third subsample, which we refer to as the $R D$ sample, restricts the full sample to workers employed by firms in a window of 20 employees on either side of the firm size discontinuity in the rights to representation, which occurs at 30 employees. ${ }^{7}$ The final subsample, which we refer to as the adoption sample, restricts to workers employed by a firm adopting worker representation for the first time between 2006 and 2012. ${ }^{8}$ By limiting the time period to these years, we can require all workers to be employed by the adopting firms at least two years before and at least three years after the year in which a worker representative is elected. This ensures that changes in the composition of workers within adopting firms do not affect our results.

\footnotetext{
${ }^{7}$ Even though the regulation creates several discontinuities in the rights to representation, we focus on the discontinuity in the rights to worker representation created by the 30 employees threshold, i.e. on the extensive margin of worker representation. This is the most relevant margin for policymakers interested in the effects on wages of introducing worker representation on the corporate board of a given firm.

${ }^{8}$ We assume that worker representation is an absorbing state, since we observe only a small number of firms choosing to discontinue worker representation after once having adopted.
} 
Table 1: Overview of the sample restrictions.

\begin{tabular}{|c|c|c|c|c|c|}
\hline & \multirow[b]{2}{*}{$(1)$} & \multicolumn{4}{|c|}{ Subsamples } \\
\hline & & $(2)$ & $(3)$ & $(4)$ & $(5)$ \\
\hline & Full sample & Movers & Stayers & $\mathrm{RD}$ & Adoption \\
\hline \multicolumn{6}{|l|}{ Observation counts } \\
\hline Unique workers & $1,561,744$ & 31,154 & 336,866 & 627,142 & 19,239 \\
\hline Unique firms & 127,741 & 9,119 & 46,397 & 28,589 & 789 \\
\hline \multicolumn{6}{|l|}{ Subsample restrictions } \\
\hline Job-to-job transition between 2005 and 2012 & & $\checkmark$ & & & \\
\hline Employed by firm for at least six years & & & $\checkmark$ & & \\
\hline Employer firm size between 10 and 50 & & & & $\checkmark$ & \\
\hline Employer adopted worker representation between 2006 and 2012 & & & & & $\checkmark$ \\
\hline
\end{tabular}

Notes: This table provides an overview of the baseline sample and the sample restrictions imposed to construct each of the four subsamples used in the analyses. In the RD sample, firm size refers to the number of employees in the firm, measured in January of the year before the year in which we measure worker representation status and wages.

Appendix Table B.1 compares the characteristics and sizes of the full sample and each of the four different subsamples. The firms and workers are broadly similar across the different samples on both worker and firm characteristics. Notably, the distributions of wages, hours worked, and total earnings are very similar across all the subsamples. Firms in the movers and stayers samples are also similar in terms of size, age, and industry composition. The adoption sample, on the other hand, consists of younger and smaller firms, with a higher degree of unionization. By construction, the RD sample also consists of markedly smaller firms than the other samples. These firms also have lower rates of unionization and a different industry composition than the full sample of firms.

\section{Institutional setting and descriptive evidence}

In this section, we begin by reviewing the role of worker representatives on corporate boards, the regulation governing the rights to worker representation, and some key features of wage setting in Norway. Against this background, we then present descriptive statistics of firm-level correlates with worker representation and the observed wage differences between workers in firms with and without worker representation.

\subsection{Corporate boards and worker representation}

Corporate governance in Norway is based on similar structures as in the US, the UK, and several other European countries, with a single-tiered board of directors. In a single-tiered system, the 
corporate board is involved in the day-to-day operations of the firm and responsible for hiring the CEO, setting the compensation of managers, and for managing long-term plans and budgets. Germany and a few other countries ${ }^{9}$, on the other hand, have two-tiered systems with both a supervisory board and an executive board. The executive board is involved in day-to-day operations of the firm, while the supervisory board is primarily engaged in long-term planning and supervision of the executive board. In two-tiered systems, workers are generally represented at the supervisory board.

In Norway, workers' right to representation on the corporate board was established as an institution in 1972, with legal regulations provided by the Norwegian Limited Liability Companies Act ("Aksjeloven"). Worker representatives are elected by and among the employees, not the shareholders, but have the same rights and responsibilities as regular board members elected by the shareholders. The law specifies workers' right to representation as a discontinuous function of firm size: In firms with less than 30 employees, workers have no rights to representation on the board (but worker representation is not actively discouraged); in firms with between 30 and 50 employees, workers can demand at least one representative on the corporate board; in firms with between 50 and 200 employees, workers can demand at least two representatives and up to one third of the board members; and in firms with more than 200 employees, worker representation on the corporate board is mandatory unless workers are represented on the firm's corporate assembly or on the corporate board of a different firm within the same corporate group (a group of firms with common ownership). ${ }^{10}$ Firms expecting to be only temporarily above a given firm size threshold can apply to be exempt from the regulation, and the general regulation does not apply to firms operating in industries with industry-specific regulations. ${ }^{11}$

Figure 1 shows that worker representation on the corporate board is a pervasive institution in the Norwegian labor market. In our full sample, about $40 \%$ of workers are employed by firms with at least one worker representative on the corporate board. The figure also shows that the prevalence of worker representation is increasing with firm size: The share of workers represented at the corporate board ranges from about $3 \%$ for workers in firms with less than 30 employees to nearly $80 \%$ in firms with more than 200 employees.

\subsubsection{Wage determination, labor unions, and worker representatives}

The Norwegian labor market is characterized by a relatively high coverage of collective bargaining agreements. Nevertheless, there is substantial room for individual firms to adjust wages. In the most common form of collective agreements in the private sector, general guidelines or minimum wages are established at the industry-level while bargaining takes place at the firm-level. According

\footnotetext{
${ }^{9}$ These countries include Austria, Denmark, and Poland. In France, firms are free to choose between a two-tiered and a single-tiered system.

${ }^{10}$ The corporate assembly is similar to the supervisory board in two-tiered systems, and one-third of the members must be elected by the employees.

${ }^{11}$ Exempt industries include newspapers and media, bank and insurance, and off-shore drilling. These industries are subject to other regulations.
} 


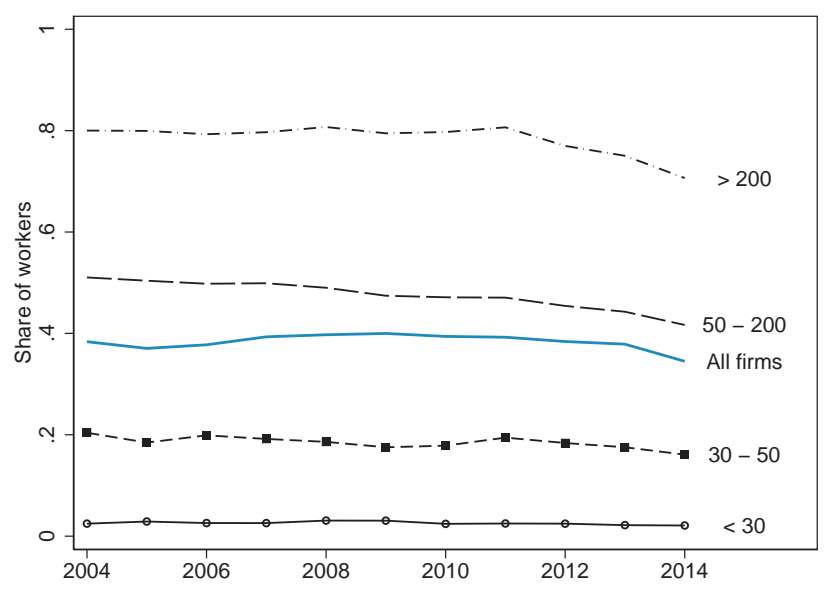

Figure 1: Share of workers represented at the corporate board by employer firm size.

Notes: This figure shows the share of workers employed by a firm with at least one worker representative on the corporate board. Firms are categorized by the number of employees in January of year $t-1$, and each line represents a separate firm size category. The figure is constructed using the baseline worker sample defined in Section 2.

to the 2012 Norwegian Workplace Survey, these agreements cover about 50\% of private sector workers. Moreover, about 30\% of workers are not covered by collective agreements. This means that individual firms can have considerable influence on wages for about $80 \%$ of all private sector workers. For the remaining $20 \%$ of workers, all bargaining takes place at the sector- or industrylevel. $^{12}$

Union representatives are the voice of the workers within the firm and play a key role in firmlevel negotiations. In contrast to worker representatives, there are no legal regulations creating links between firm size and the influence of unions. Instead, union rights are determined by the share of workers who pay union dues. Within the firm, union representatives bargain with the management of the firm on behalf of their members. Besides participating in negotiations, local union representatives often provide support, information, and advice to members of the union. And while labor unions and worker representation on corporate boards are distinct entities, they are likely to be closely related in practice: Union representatives can provide information about workers' rights to representation on the corporate board, organize and participate in elections, and provide information and training to those elected to serve as worker representatives on the board. Nevertheless, the channels through which a worker representative and a union representative can influence worker compensation are different. Worker representatives serve on the board with the same rights and responsibilities as regular board members, and can propose and vote for firm-wide bonus schemes, executive pay schemes, demand to institute a collective agreement, and influence the overall strategy of the firm for the firm-level negotiations with the union representatives.

\footnotetext{
${ }^{12}$ See Dale-Olsen et al. (2018) for an in-depth description of collective bargaining in Norway.
} 


\subsection{Descriptive evidence}

Before turning to the identification and estimation of the two sets of causal parameters, we here present and discuss the results from a descriptive analysis of firm-level correlates with worker representation and the wage differences between workers in firms with and without worker representation.

\subsubsection{Firm-level correlates with worker representation}

Figure 2 shows differences in the rates of worker representation between firms with different observable characteristics. Firms with worker representation are generally larger, more unionized, and older than firms without representation. This pattern persists when we regress the indicator for worker representation on all observed firm characteristics: Firms with more than 200 employees are 58 percentage points more likely than firms with less than 30 employees to have at least one worker representative on the corporate board, conditional on all other observed firm characteristics. Similarly, workers in firms in which more than $50 \%$ of the workers are unionized are 25 percentage points more likely to be represented on the corporate board than workers in firms where less than $10 \%$ of the workers are unionized.

In Appendix Figure B.1 we complement the correlations by comparing the explanatory power of each observed characteristic in the regressions from Figure 2. The partial $R^{2} \mathrm{~s}$ are normalized to sum to one such that each of the reported values can be directly interpreted as the share of explained variability that is attributable to an observable aspect of the firm. Firm size is the most important predictor of whether the firm has worker representation and accounts for about $75 \%$ of the explained variability in rates of worker representation across firms.

\subsubsection{Average wage levels}

Figure 3 plots differences in log hourly wages between workers in firms with and without worker representation. On average, workers in firms with worker representation earn about $16 \%$ more per hour than workers in firms without representation. This raw wage difference varies with the skill level and union membership status of workers, and is larger for high-skilled and non-unionized workers than for low-skilled and unionized workers. Each bar in the figure adds a set of controls for pre-determined firm and worker characteristics. Controlling for observable characteristics significantly reduces the differences in wage levels between workers in firms with and without representation, suggesting that omitted variable bias is a major threat to identification in this setting. Nevertheless, even after controlling for observables, workers in firms with worker representation still earn about $2 \%$ more per hour than workers in similar firms without representation. 


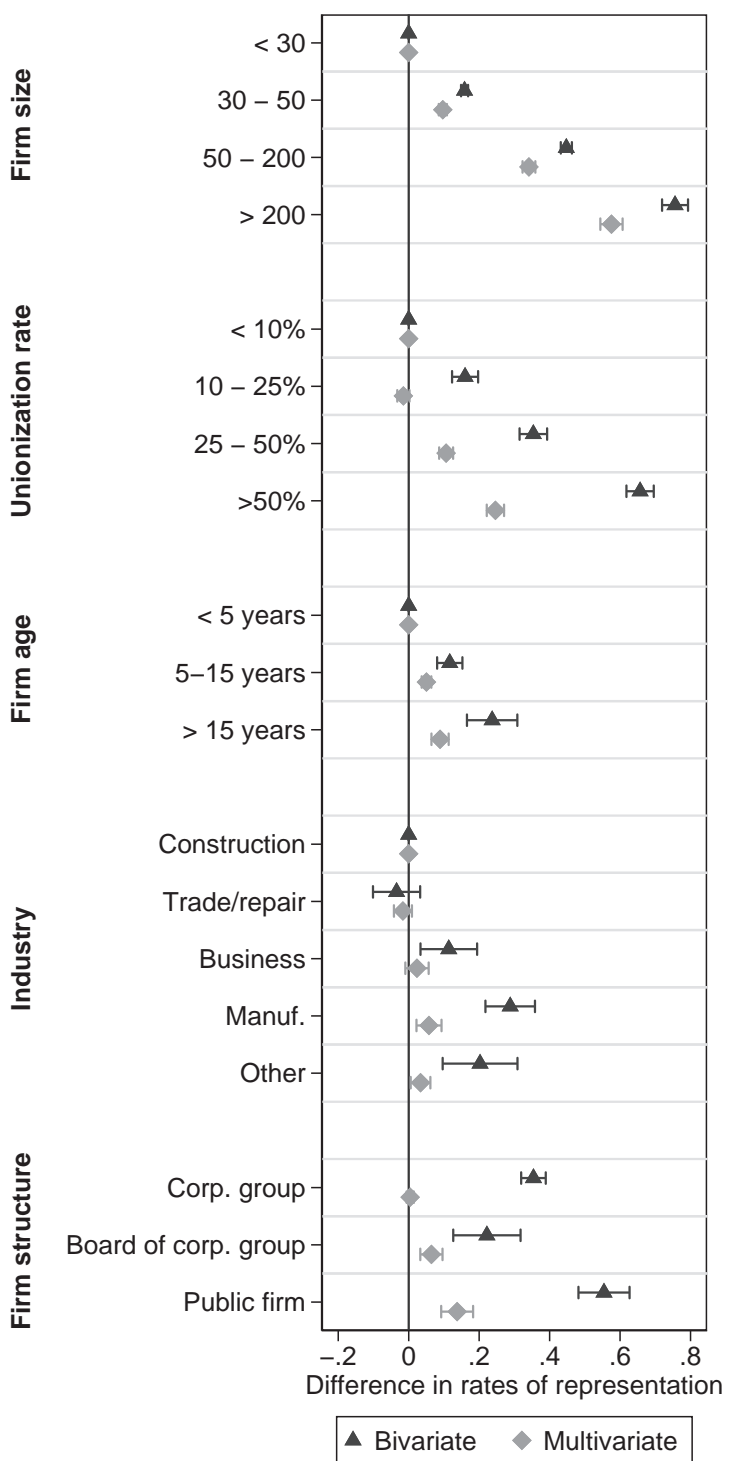

Figure 2: Firm characteristics correlated with worker representation.

Notes: This figure plots the coefficients from a regression of an indicator for whether the firm has at least one worker representative on the corporate board on different firm-level characteristics ("bivariate"). The "multivariate" coefficients are from a regression of an indicator for whether the firm has at least one worker representative on the corporate board on all the pre-determined firm characteristics simultaneously. The firm characteristics are defined in Appendix Table A.1, and the sample used is the baseline sample as defined in Section 2. The horizontal lines show 90\% confidence intervals constructed using standard errors clustered at the firm-level. We measure the firm characteristics in year $t-1$, to ensure that they are pre-determined relative to when we measure worker representation. 


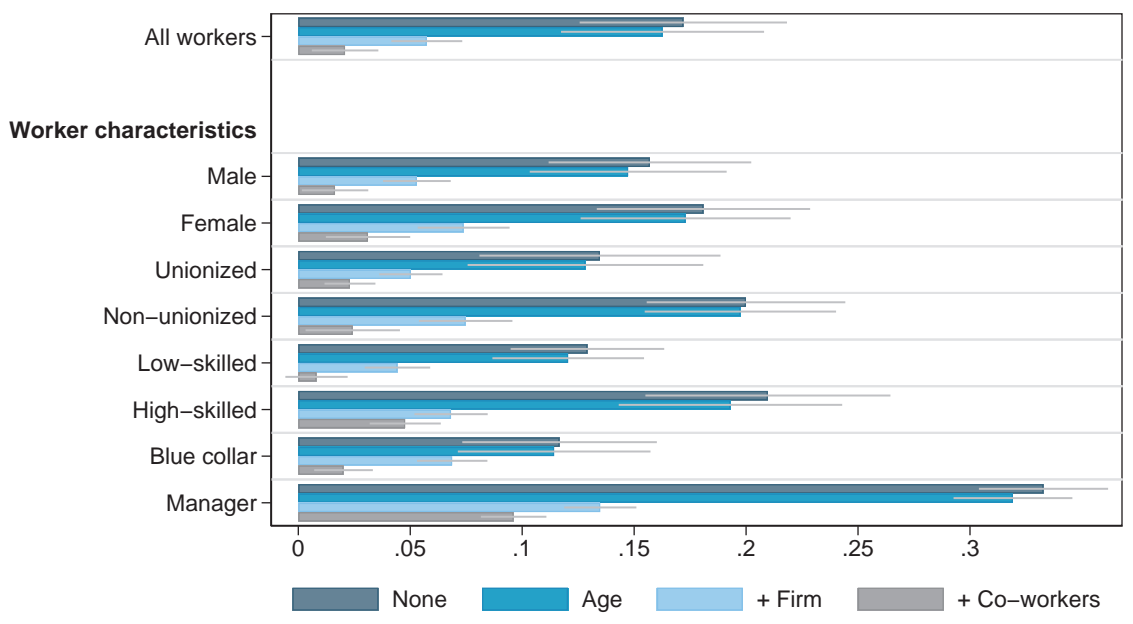

Figure 3: Observed differences in log hourly wages.

Notes: This figure plots the coefficients from a regression of log hourly wages on an indicator for whether the firm has at least one worker representative on the corporate board, estimated for all workers in the baseline sample and separately for subgroups of workers with different characteristics. The worker characteristics are defined in Appendix Table A.1. In the first set of bars, there are no controls included. The second set of bars controls for a cubic polynomial in the worker's age. The third set of bars additionally controls for year fixed effects, industry fixed effects, region (of the firm) fixed effects, whether the firm is publicly listed, whether the firm is part of a corporate group, and whether the board represents the entire corporate group. The last set of bars also controls for the average age of workers in the firm, the immigrant share, the share of workers that are male, the share of workers that are unionized, and the share of high-skilled workers. The gray lines on the bars show $90 \%$ confidence intervals constructed using standard errors clustered at the firm-level, and the sample used is the baseline sample as defined in Section 2.

\section{Impacts of working in a firm with worker representation}

The descriptive evidence presented in the previous section shows that workers in firms with worker representation earn more than other workers. However, this raw wage difference could be entirely driven by sorting of workers of higher quality into firms with worker representation. To address this concern, we now apply research designs that control for unobserved worker heterogeneity in order to draw causal inferences about the impacts of working in a firm with worker representation.

\subsection{Worker representation wage premium}

We first examine whether firms with worker representation pay systematically higher wages than firms without; that is, whether there exists a worker representation wage premium. We use a difference-in-differences (DiD) framework comparing the wage growth of co-workers, where one worker switches to a firm with worker representation and the other to a firm without.

To provide a graphical illustration of the research design, it is helpful to recenter the data such that the moves occur at time zero. In particular, we estimate the following time-varying $\mathrm{DiD}$ 
specification:

$$
w_{i, s}=\alpha_{i}+\pi_{s}+\sum_{k=-3}^{3} \tau_{k} \mathbf{1}[s=k, G(i)=1]+\epsilon_{i, s},
$$

where $s$ denotes year relative to when the worker switched firms, $\alpha_{i}$ is a worker fixed effect that captures the returns to time-invariant worker characteristics (such as ability), $\pi_{s}$ denotes time effects, and $G(i)$ is an indicator for whether worker $i$ switched to a firm with worker representation. The error term $\epsilon_{i, s}$ includes unobserved transitory wage determinants. We measure the worker representation status of both origin and destination firms in year $s=-2$, to make sure it is

predetermined relative to the year of the move. The coefficients of interest $\tau_{k}$ capture the wage impact of working in a firm with worker representation, measured $k$ years before or after the move. To summarize the estimates, we also construct a single estimate of the wage impact of working in a firm with worker representation by replacing the period-specific indicators $\mathbf{1}[s=k, G(i)=1]$ and the corresponding coefficients $\tau_{k}$ with a single post-treatment indicator $\mathbf{1}[k>0, G(i)=1]$ and a single coefficient $\tau^{\text {post }}$. In the year of the move $(k=0)$, workers are partially treated and we measure wages as the employment-duration weighted average of wages in the new and old job. For this reason, we exclude the year of the move from the post-treatment estimates.

\subsubsection{Threats to identification and external validity}

By including a worker fixed effect $\left(\alpha_{i}\right)$, we control for any time-invariant worker heterogeneity affecting both wages and whether the person moves to a firm with worker representation. Aggregate shocks that are common to both groups over time are absorbed by the time effects. The identifying assumption is a common trend assumption, implying that the wage growth of workers moving to a firm without representation is a valid counterfactual for those moving to a firm with worker representation.

In terms of the internal validity of the estimated wage premia from equation (1), there are some potential concerns related to the possibility that worker mobility is driven either by transitory wage shocks or by firm shocks at the origin firm. First, workers who experience negative shocks to their own productivity might sort into firms with worker representation, where compensation could be less tied to the worker's short-term performance. If this were the case, we would expect the wage growth of workers in the treatment group to be lower than that of the comparison group in the years before the move. In our DiD analysis, we find no evidence of such pre-trends: the treatment and comparison groups do not differ significantly in their wage growth in the years before the move. Second, workers in firms experiencing negative shocks to performance may be more likely to move to firms with worker representation, where job security might be higher. In this case, the estimated worker representation wage premium would be overstated. However, by having control groups that consist of co-workers in the same origin firm moving to different destination firms, we can control for firm-wide shocks in the pre-period.

In addition to the threats to internal validity, one may be concerned that the estimated wage effects for workers moving into a firm with worker representation are not representative for the pop- 
ulation of workers at large. In particular, if workers sort into firms with worker representation based on match effects that are correlated with worker representation, the wage effects for the treatment group movers could be overstated relative to the wage effects for the average worker. For example, individualized wage bargaining could be more prominent in firms with worker representation, and workers selecting into these firms might be more productive and more adept at bargaining. If mobility between firms with different worker representation status is driven by sorting on match effects, we would expect wage gains associated both with moving into and with moving out of a firm with worker representation, relative to their comparison groups, for whom there is no change in the match effect. In the DiD analysis below, we examine this implication by conducting a separate analysis for workers moving out of a firm with worker representation. Comparing these results with those based on workers moving into a firm with worker representation, we find wage impacts that are similar in magnitude and opposite in sign. This symmetry is consistent with our log-additive model that assumes no systematic match effects, indicating that the worker representation wage premium may be representative for the overall population of workers.

\subsubsection{Difference-in-Differences analyses}

Figure 4 plots the DiD estimates $\tau_{k}$ from the specification in equation (1), for $k \in\{-3, \ldots, 3\}$. We normalize the estimates to be relative to two years before the move by setting $\tau_{-2}=0$. The dashed horizontal line represents the treatment effect for the post-treatment period $(k>0)$. Panel (a) considers workers switching into a firm with worker representation, while Panel (b) considers workers switching from a firm with representation to one without.

Reassuringly, we find no evidence of significant differences in pre-trends. In the years before the move, the wage growth of workers in the treated and comparison groups are very similar, and none of the pre-period estimates are significantly different from zero at conventional levels. The similarity in pre-trends supports the identifying assumption, and thus, indicates that the wage growth of the comparison groups may provide a valid counterfactual for the wage growth of the treated groups. As a result, the post-treatment estimates have a causal interpretation as the impacts of working in a firm with worker representation.

On average, workers switching into a firm with worker representation experience a $4.3 \%$ increase in wages in the years after the move as compared to workers in the comparison group. Conversely, workers switching out of a firm with worker representation experience, on average, a $3.4 \%$ decrease in wages in the years after the move as compared to workers in the comparison group.

Table 2 shows the sensitivity of the DiD estimates to controlling for workers' age, as well as for differential time effects by the year of the move, origin firm fixed effects, and the interaction between the two. Our baseline estimates, with controls for worker fixed effects and time effects, are presented in Column 1. Column 2 controls for a cubic polynomial in age. The third column adds controls for a full set of indicators for the year of the move interacted with a post-treatment indicator. This specification accounts for aggregate calendar year effects which could affect both wage growth and the decision to switch between firms with different worker representation status. Moving 


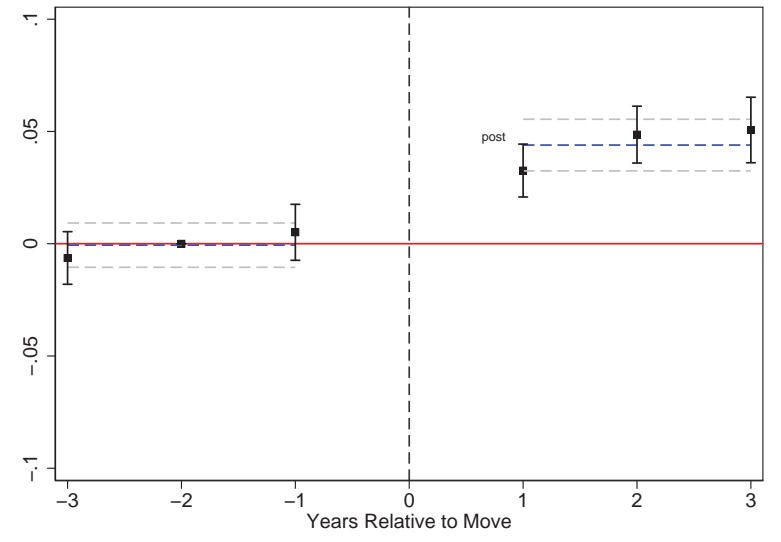

(a) Into treatment

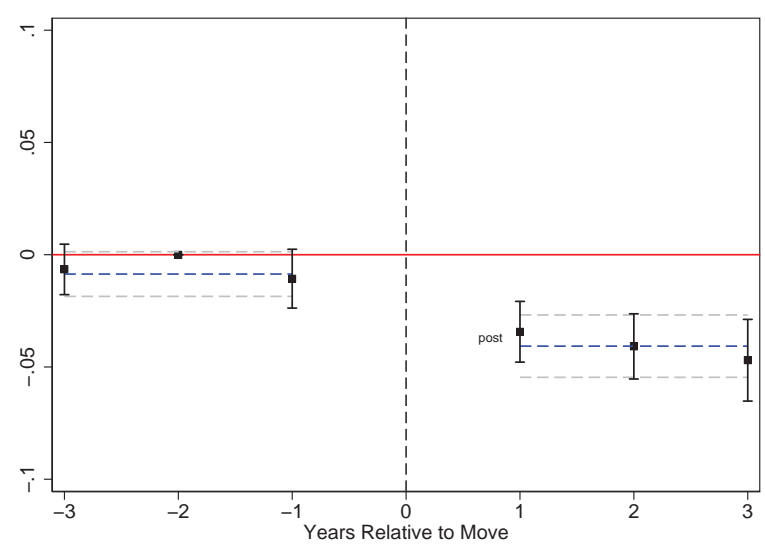

(b) Out of treatment

Figure 4: Graphical evidence: Worker representation wage premium

Notes: These figures plot the estimated $\tau_{k}$ coefficients (along with 95\% confidence intervals) from the specification in equation (1), for $k \in\{-3, \ldots, 3\}$. The parameter $\tau^{\text {post }}$ indicates the impact in the post-treatment period ( $\left.k>0\right)$. In Panel (a), the treatment group includes workers switching from a firm without representation to a firm with representation, while the comparison group includes workers switching between two firms without representation. In Panel (b), the treatment group includes workers switching from a firm with representation to a firm without representation, while the comparison group includes workers switching between two firms with representation. The sample used is the movers sample as defined in Section 2.

from Column 3 to Column 4, we include origin firm fixed effects interacted with a post-treatment indicator. The last column also includes a full set of year of move-by-origin firm fixed effects interacted with a post-treatment indicator. With this specification, we are effectively comparing workers in the same firm switching jobs in the same year. It is reassuring to find that the worker representation wage premium does not change considerably across specifications. 
Table 2: Sensitivity of the worker representation wage premium.

\begin{tabular}{|c|c|c|c|c|c|}
\hline & (1) & $(2)$ & $(3)$ & $(4)$ & $(5)$ \\
\hline \multicolumn{6}{|l|}{ Panel A. Into-treatment movers } \\
\hline \multirow[t]{2}{*}{ Post x Into-treatment } & 0.043 & 0.042 & 0.043 & 0.035 & 0.034 \\
\hline & $(0.005)$ & $(0.005)$ & $(0.005)$ & $(0.005)$ & $(0.005)$ \\
\hline Nr. of firms & 4,874 & 4,874 & 4,874 & 4,874 & 4,874 \\
\hline Nr. of worker-year obs. & 47,721 & 47,721 & 47,721 & 47,721 & 47,721 \\
\hline \multicolumn{6}{|l|}{ Panel B. Out-of-treatment movers } \\
\hline \multirow{2}{*}{ Post x Out-of-treatment } & -0.034 & -0.039 & -0.039 & -0.035 & -0.037 \\
\hline & $(0.006)$ & $(0.006)$ & $(0.006)$ & $(0.004)$ & $(0.004)$ \\
\hline Nr. of firms & 5,606 & 5,606 & 5,606 & 5,606 & 5,606 \\
\hline Nr. of worker-year obs. & 98,219 & 98,219 & 98,219 & 98,219 & 98,219 \\
\hline \multicolumn{6}{|l|}{ Conrols } \\
\hline Worker FE & $\mathrm{x}$ & $\mathrm{x}$ & $\mathrm{x}$ & $\mathrm{x}$ & $\mathrm{x}$ \\
\hline Post & $\mathrm{x}$ & $\mathrm{x}$ & $\mathrm{x}$ & $\mathrm{x}$ & $\mathrm{x}$ \\
\hline Age (cubic) & & $\mathrm{x}$ & $\mathrm{x}$ & $\mathrm{x}$ & $\mathrm{x}$ \\
\hline Move year FE x Post & & & $\mathrm{x}$ & $\mathrm{x}$ & $\mathrm{x}$ \\
\hline Old firm FE x Post & & & & $\mathrm{x}$ & $\mathrm{x}$ \\
\hline Move year FE x Old firm FE x Post & & & & & $\mathrm{x}$ \\
\hline
\end{tabular}

Notes: This table reports estimated worker representation wage premia from a version of equation (1) where the period-specific indicators $\mathbf{1}[s=k, G(i)=1]$ and the corresponding coefficients $\tau_{k}$ are replaced with a single posttreatment indicator $\mathbf{1}[k>0, G(i)=1]$ and a single coefficient $\tau^{\text {post }}$. In Panel A, the treatment group includes workers switching from a firm without representation to a firm with representation, while the comparison group includes workers switching between two firms without representation. In Panel B, the treatment group includes workers switching from a firm with representation to a firm without representation, while the comparison group includes workers switching between two firms with representation. Column 1 reports the post-treatment effect from the baseline specification with controls for worker fixed effects and event time effects. Column 2 adds a cubic polynomial in the age of the worker. Column 3 adds indicators for the year of the move interacted with the post-treatment indicator. Column 4 adds indicators for the origin firm interacted with the post-treatment indicator. Column 5 also includes a full set of year of move-by-origin firm fixed effects interacted with the post-treatment indicator. The sample used is the movers sample as defined in Section 2. Standard errors are clustered at the firm-level. 


\subsection{Pass-through of firm shocks to wages}

In the previous section, we found a significant wage premium associated with working in a firm with worker representation. We now examine the sensitivity of wages to fluctuations in firm performance, and ask whether firms with and without worker representation differ in the extent to which changes in firm performance are passed through to wages.

To estimate the pass-through of idiosyncratic firm shocks to wages, we focus on the stayers subsample. Restricting to stayers allows us to control for time-invariant worker and firm unobservables, and ensures that our results are not affected by changes in the composition of workers within firms in response to the shocks. We estimate the following statistical model of hourly wages;

$$
w_{i, t}=\phi_{j(i)}+\gamma y_{j(i), t}+X_{i, t}^{\prime} \delta+\epsilon_{i, t}
$$

where $y_{j(i), t}$ is the $(\log )$ value added in year $t$ of firm $j$, and $\phi_{j(i)}$ is a fixed effect for worker $i$ if she works in firm $j$, capturing time-invariant observed and unobserved characteristics of the firm and worker. The vector $X$ consists of time-varying controls and includes a cubic polynomial in worker age and a full set of (two-digit) industry-by-year indicators, absorbing aggregate economic or industry time shocks which could affect both firm value added and wages. We estimate equation (2) separately for firms with and without worker representation, treating worker representation as a time-invariant characteristic of the worker-firm match. To make sure it is pre-determined relative to the value added shock, we measure the worker representation status of each worker in the first year the worker is employed by the firm.

Our parameter of interest $\gamma$ measures the pass-through rate of an idiosyncratic value added shock to the wages of incumbent workers. This pass-through rate could be informative about the degree of wage insurance offered by employers, as studied by the literature on insurance within the firm (see e.g. Guiso et al., 2005; Juhn et al., 2018; Balke and Lamadon, 2020).

\subsubsection{Difference-in-Differences illustration}

Our baseline specification (2) includes fixed effects for both agents and time, essentially comparing wages and value added within workers and firms while eliminating common changes over time. As in the usual DiD design, identification of the pass-through rate requires a common trend assumption.

Figure 5 provides a visual inspection of the common trend assumption. To construct this figure, we proceed as follows: In any given calendar year (denoted period $t=0$ ), we (i) order the firms according to the growth in value added net of industry specific shocks and spell fixed effects; (ii) separate the firms at the median in the distribution of (residualized) value added growth, letting the upper half be the treatment group and the lower half the control group; and (iii) plot the differences in residualized $\log$ value added between these two groups in period $t=0$ as well as in the years before (periods $t<0$ ) and after (periods $t>0$ ). We perform these three steps separately for each calendar year, always weighting each firm by the number of workers.

By construction, the treatment and control groups differ in the growth of residualized value 
added from $t=-1$ to $t=0$, as shown in Panel (a). On average, firms in the treatment group experience almost 30 percent larger growth in value added compared with firms in the control group. Reassuringly, firms that experience larger growth in value added in period 0 are no more or less likely to experience large growth in value added in periods -5 to -2 , supporting the assumption that the control group firms provide a valid counterfactual for the value added growth of treatment group firms. In Panel (b), we plot the differences in residualized log value added between the treatment and control group for each calendar year, and find that the firm shocks are similar in magnitude across years.

In Panel (c), we perform the same steps as in Panels (a) and (b), but now separately for firms with and without worker representation. For both groups of firms, the treatment group experiences almost 30 percent larger growth in value added than the control group, and the differences between the treatment and control group firms are stable between periods -5 and -2 .

Panel (d) performs the same exercise, but this time for residualized log hourly wages of incumbent workers who stay in the firm for at least six years. On average, incumbent workers in firms with worker representation experience a $1 \%$ increase in hourly wages from $t=-1$ to $t=0$. By comparison, incumbent workers in firms without worker representation experience about a $3 \%$ increase. Taken together with Panel (c), these figures imply a pass-through rate of value added shocks to wages of around 0.02-0.03 for workers in firms with worker representation, and about 0.09-0.1 for workers in firms without representation.

\subsubsection{Pass-through estimates}

We now present point estimates of the pass-through rates and test whether there is a significant difference in the pass-through rates of firms with worker representation and those without. Table 3 reports the results from estimating equation (2) using OLS, separately by whether the firm has worker representation or not. The estimates are consistent with the conclusions from the DiD analysis: In response to a 10 percent decrease in firm value added, wages of incumbent workers in firms with representation decrease by 0.2 percent, while wages of workers in firms without representation decrease by almost 0.9 percent. In the second row of Table 3, we estimate the pass-through rates using log value added per worker. With both measures of firm performance, we find large and significant differences in the pass-through of value added shocks to wages between firms with and without worker representation: 0.066 and 0.051 percentage points, respectively, in response to a $10 \%$ change in value added and value added per worker. 


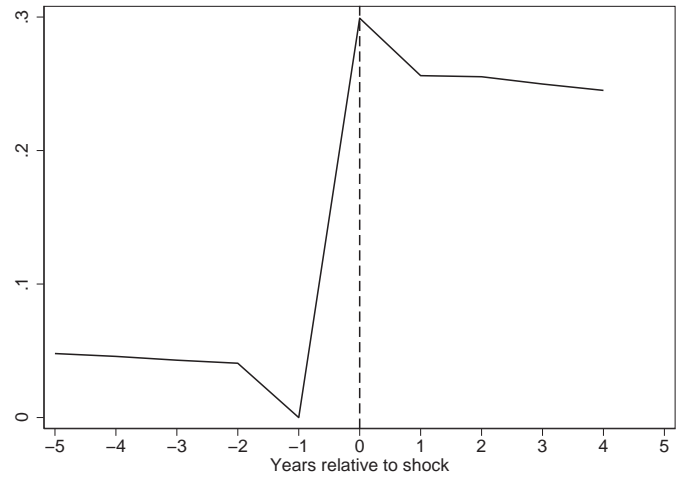

(a) Residualized (log) Value added

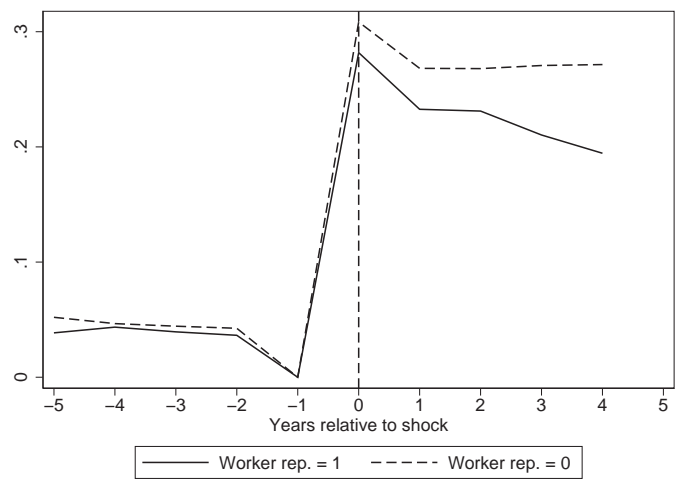

(c) Residualized (log) Value added

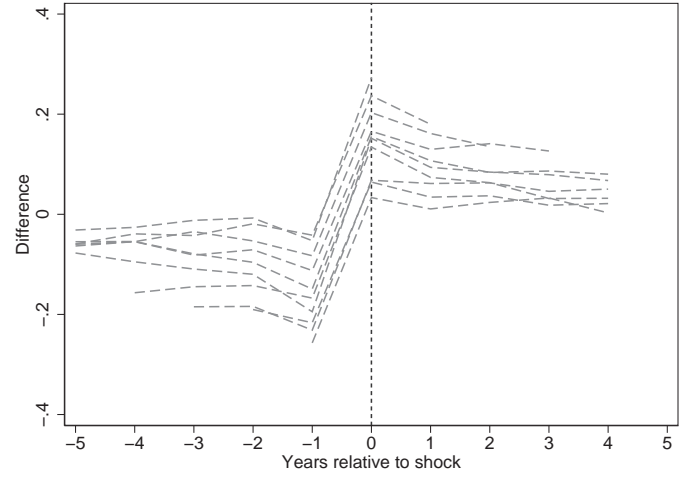

(b) All calendar years

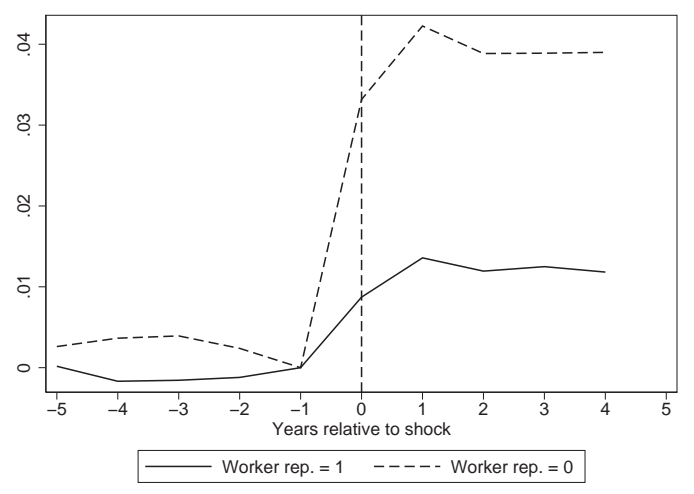

(d) Residualized (log) Hourly wage

Figure 5: Difference-in-differences representation of the pass-through estimation.

Notes: This figure illustrates the identification strategy using a difference-in-differences framework. Panel (a) plots the differences in residualized value added between the treatment and control groups, as defined in the text. Panel (b) plots the same differences separately for each calendar year, where the data is centered such that each dotted line at period $t=0$ corresponds to a separate calendar year. Panels (c) and (d) perform the steps in (a) and (b) separately for stayers in firms with and without worker representation, for residualized value added and wages, respectively. The sample used is the stayers sample as defined in Section 2. 
Table 3: Estimated pass-through rates by firms' worker representation status.

\begin{tabular}{|c|c|c|c|c|}
\hline & \multicolumn{2}{|c|}{ Estimated pass-through rate $\gamma$} & \multirow[b]{2}{*}{$(3)$} & \multirow[b]{2}{*}{$(4)$} \\
\hline & (1) & $(2)$ & & \\
\hline & Worker representation & No worker representation & $\begin{array}{c}\text { Difference in } \\
\text { pass-through rates } \\
(1)-(2)\end{array}$ & p-value $(1)=(2)$ \\
\hline \multicolumn{5}{|l|}{ Measure of firm performance: } \\
\hline \multirow[t]{2}{*}{$(\log )$ Value Added } & 0.022 & 0.088 & -0.066 & 0.000 \\
\hline & $(0.004)$ & $(0.003)$ & $(0.005)$ & \\
\hline \multirow[t]{2}{*}{$(\log )$ Value added pr. worker } & 0.013 & 0.063 & -0.051 & 0.000 \\
\hline & $(0.003)$ & $(0.003)$ & $(0.004)$ & \\
\hline Nr. of firms & 1,520 & 44,877 & 46,397 & \\
\hline Nr. of worker-year observations & 828,688 & $1,579,477$ & $2,408,165$ & \\
\hline
\end{tabular}

Notes: This table shows estimated pass-through rates from equation (2), for two different measures of firm performance; log value added and log value added per worker. Column 1 restricts to job spells where the worker is employed by a firm with at least one worker representative in the first year of the spell. Similarly, Column 2 restricts to workers employed by firms without worker representation in the first year of the spell. Column 3 reports the difference in pass-through estimates between Columns 1 and 2. Column 4 reports p-values for the null hypothesis that the passthrough rates in Columns 1 and 2 are equal. Standard errors are clustered at the firm-level. The standard errors and p-values for the difference in point estimates are obtained by fully interacting equation (2) with an indicator for worker representation. The sample used is the stayers sample as defined in Section 2. 


\section{$5 \quad$ Effects of adopting worker representation}

In this section, we apply two research designs to estimate the impact of a firm exogenously adopting worker representation. Using an RD design, we first show that the regulation governing the rights to worker representation significantly increases the incidence of worker representation on corporate boards, without affecting wages. We next turn to an event study design exploiting differences across firms in the timing of adoption of worker representation, and find no evidence of any significant change in incumbent workers' compensation in the years following adoption, relative to the control group comprised of workers in firms adopting worker representation later in the sample period.

\subsection{Regression discontinuity design}

To estimate the causal effects of adopting worker representation on worker compensation, the ideal experiment would randomize worker representation on corporate boards across firms. In practice, this experiment is infeasible because we cannot force some firms to change the composition of their corporate board, while preventing others from doing so. Our RD design approximates this ideal experiment by exploiting the discontinuity in workers' rights to worker representation at the 30 employees cut-off. Workers in firms at or above the cut-off have the right to demand worker representation on the corporate board, while workers right below the cut-off have no such rights.

\subsubsection{RD setup and estimation}

We implement our RD design using the following regression model;

$$
w_{i}=\pi+\lambda T_{j(i)}+h\left(R_{j(i)}\right)+X_{j(i)}^{\prime} \delta+\nu_{i},
$$

where $w_{i}$ denotes the $\log$ hourly wage of worker $i$ in a given year, $j(i)$ denotes the employer of worker $i$ in the same year, $R_{j(i)}$ is the number of employees in the firm measured in January of the year before, and $T_{j(i)} \equiv \mathbf{1}\left[R_{j(i)} \geq 30\right]$ is an indicator denoting whether the firm was above the firm size cut-off. The vector $X_{j(i)}$ consists of pre-determined characteristics including a full set of year, industry, and region fixed effects, whether the firm is publicly listed, whether the firm is part of a corporate group, and whether the board represents the entire corporate group. As long as firms do not perfectly manipulate the running variable (the number of employees) and there are no other changes happening discontinuously at the 30 employees cut-off, we can consistently estimate $\lambda$, the causal effect of the regulation on wages for workers in firms at the cut-off.

To implement the RD design, we specify $h(\cdot)$ as local linear regressions on each side of the cutoff, using a triangular kernel density and a window of 10 employees around the cut-off. Appendix Figure B.2 shows that the reduced form RD estimate is not sensitive to changing the bandwidth on both sides of the cut-off. We cluster the standard errors at the firm-level. 


\subsubsection{Graphical evidence}

A virtue of the RD design is that it provides a transparent way of showing how the causal effects of the regulation are identified. To this end, we begin with a graphical illustration of the firm size distribution and the distributions of pre-determined worker characteristics, before examining how the share of firms with worker representation and the hourly wages of workers vary around the firm size cut-off.

Firm size cut-off and sorting

The assignment variable in our case is firm size, which depends both on the firm's employment decision and on workers' decisions to join or leave the firm. The fact that the behavior of firms and workers may influence the running variable is not a problem per se for our regression discontinuity design. Our RD design rests on the assumption that firms do not perfectly manipulate their size so as to determine their worker representation status perfectly (see Lee and Lemieux, 2010). If they

did, for example by avoiding hiring additional workers to stay below the cut-off and thus evade demands for worker representation, we would expect to see sharp discontinuities around the cut-off - in the firm size distribution or in pre-determined characteristics.

Panel (a) of Figure 6 shows the estimated density of firms around the cut-off in each firm size bin of width two. While the unrestricted means show the underlying variation in the data, we also plot estimated local linear regression lines on each side of the firm size cut-off, to illustrate the trends in the data and the sizes of the discontinuities at the cut-off. There is no visible discontinuity in the share of observations at the 30 employees cut-off, as manipulation of the assignment variable would imply: The test proposed by McCrary (2008) is insignificant and we cannot reject the null of no sorting around the threshold. Panels (b) - (f) of Figure 6 present estimates of discontinuities in the sample means of pre-determined worker characteristics around the cut-off. Reassuringly, these RD estimates are all close to zero and insignificant.

This absence of sorting around the firm size cut-off is in line with empirical evidence from similar settings in Germany and Finland (see e.g. Lin et al., 2018; Kim et al., 2018; Redeker, 2019; Jäger et al., 2021; Harju et al., 2021) and consistent with at least two possible explanations. One is that firms are not able to manipulate (for example because of worker mobility and churning), and a second is that firms have little if any incentive to manipulate because worker representation matters little if anything for firm outcomes.

\subsubsection{Causal effects of the regulation on worker representation and wages}

In a sample covering all workers in firms with between 10 and 50 employees, there is only a small change around the cut-off in the share of workers in firms with worker representation. There are several potential reasons for this. First of all, the regulation does not prevent smaller firms from choosing to elect a worker representative. Hence, even with perfect compliance with the regulation, there would likely be some firms with worker representation below the cut-off. Moreover, some of the firms below the cut-off in year $t-1$ might have been larger in the past and decided to 


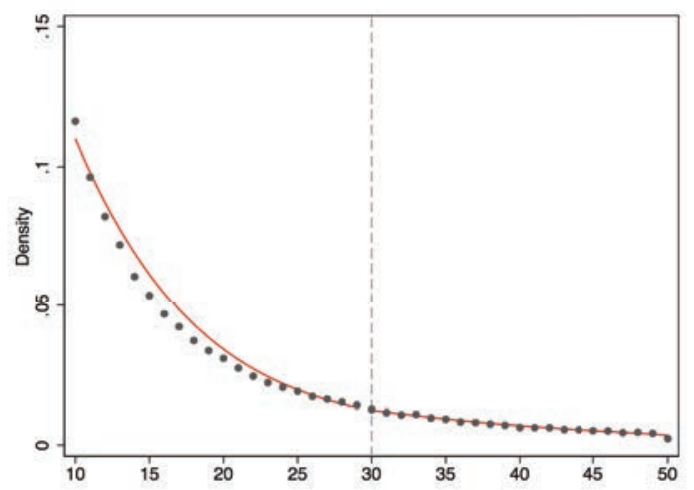

(a) Firm size distribution

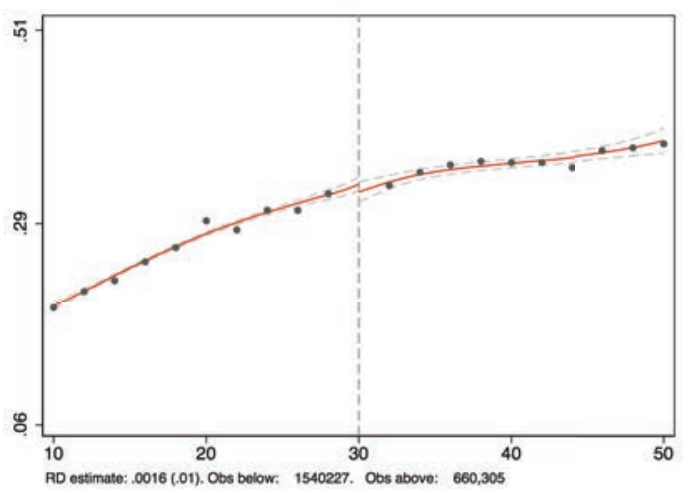

(c) Unionized

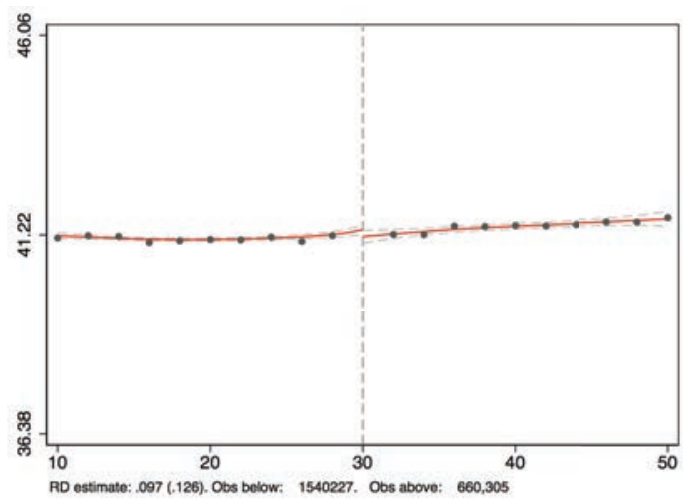

(e) Age (years)

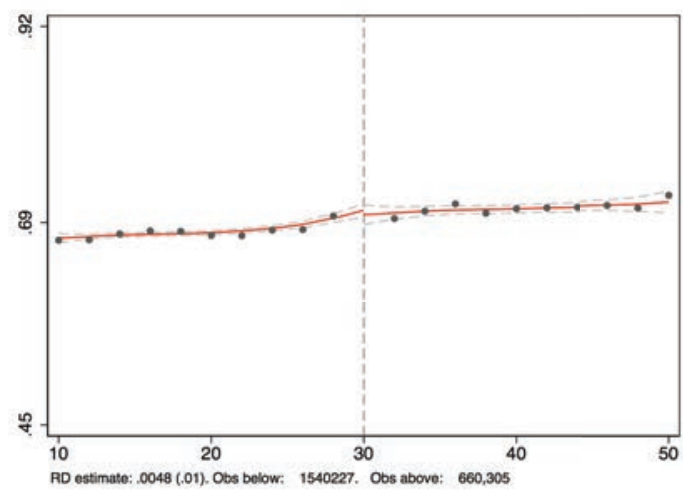

(b) Male

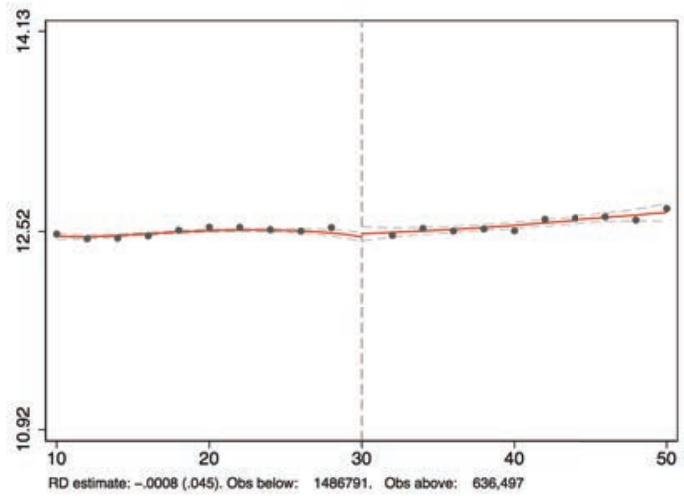

(d) Years of education

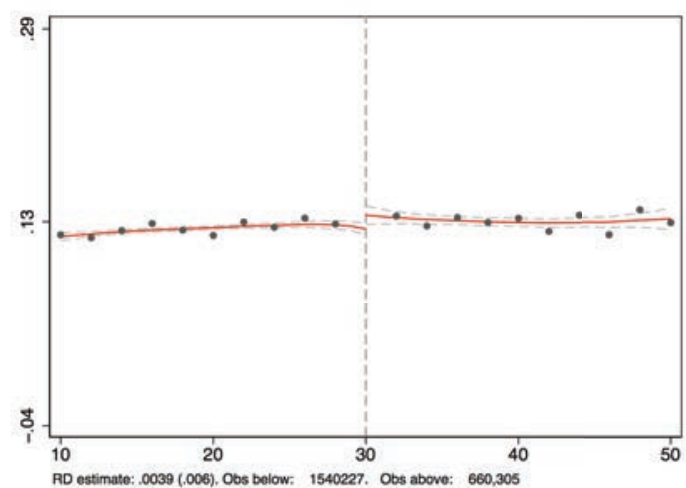

(f) Immigrant

Figure 6: Density of the assignment variable and pre-determined worker characteristics around the firm size cut-off.

Notes: Panel (a) shows the share of worker-year observations in each firm size bin. Panels (b) - (f) plot the means of pre-determined worker characteristics, where the scale of the y-axis is set equal to \pm 0.5 standard deviation of the respective variable. The worker characteristics are defined in Appendix Table A.1. The dashed vertical lines denote the regulation's firm size cut-off of 30 employees, and the sample used is the RD sample as defined in Section 2. Standard errors are clustered at the firm-level. 
continue the institution even though the number of employees dropped below 30 and the rights to representation were no longer binding by law. Furthermore, some persistence in firm size above the cut-off could be needed for firms to comply with the regulation, which states that a majority of the workers can demand representation on the corporate board if the firm has more than 30 employees. Unless the firm chooses to adopt representation voluntarily, workers would need to know that the firm employs more than 30 workers and petition for representation before they can elect a representative. If the firm is only temporarily above the cut-off, workers may not notice, or by the time they have noticed the firms can argue that they are only temporarily above the cut-off and apply for an exemption from the regulation.

In Figure 7 (a), we therefore plot the fraction of workers in firms with at least one worker representative on the board in January of year $t$ for firms that remained on either side of the cut-off for two consecutive years, $t-2$ and $t-1$. The figure shows a significant discontinuity at the cut-off, with the share of workers in firms with worker representation approximately doubling, from about 8 to 16 percent. Consistent with the visual evidence, the RD estimate shows a statistically significant 8.9 percentage points jump at the cut-off.

Using the regulation to draw conclusions about the effects of worker representation on wages requires an exclusion restriction, i.e. that the eligibility to demand worker representation in year $t-1$ only affects wages in year $t$ through the worker representation status of the firm in year $t$. Our finding that some persistence in firm size is required before the regulation affects the incidence of worker representation on corporate boards implies that this exclusion restriction is unlikely to hold: Conditional on current firm size, past firm size is likely to affect contemporaneous wages through other factors than just the right to worker representation. Nevertheless, we can still consistently estimate the causal effect of the regulation on wages for workers in firms at the cut-off.

Figure 7 (b) illustrates the effect of the regulation on log hourly wages of workers. We plot the mean of residualized (log) hourly wages in each firm-size bin and the estimated means using local linear regressions on each side of the cut-off, and standardize the scale of the y-axis to \pm 0.5 standard deviation of residualized log hourly wages. There is no visible discontinuous change in hourly wages around the cut-off. Consistent with the graphical evidence, the estimated size of the jump in hourly wages using equation (3) is only -0.9 percent, and not significantly different from zero at conventional levels.

Panel A of Table 4 presents OLS and reduced form RD estimates, for all workers and separately for different groups of workers. In the OLS specification, we regress log hourly wages on an indicator for whether the worker is employed by a firm with worker representation, controlling for predetermined firm characteristics. For all subgroups, workers in firms with worker representation earn significantly higher hourly wages than workers in firms without representation. In contrast to the positive OLS estimates, the effects on hourly wages are all close to zero or negative. Only 1 out of 8 estimated reduced form effects are significantly different from zero. The one significant effect (for unionized workers) is negative, suggesting that, if anything, adopting worker representation may reduce wages. However, given the large number of worker subgroups, the probability of observing 


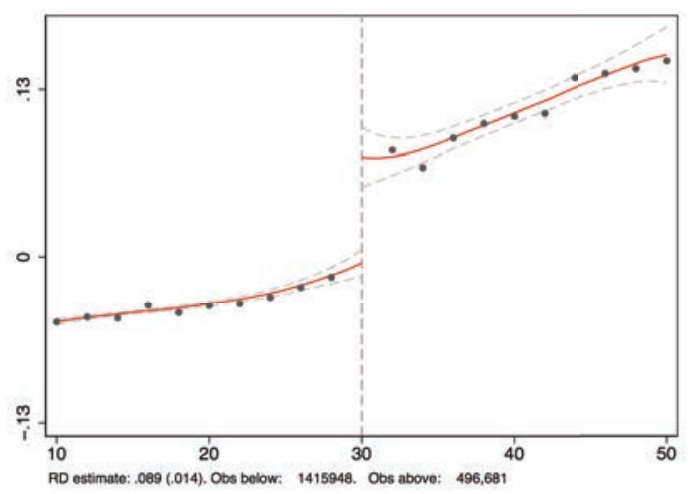

(a) Worker representation

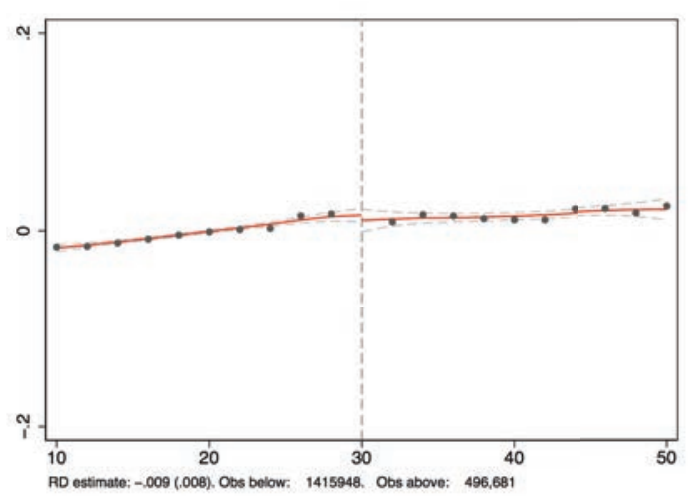

(b) (log) Hourly wages

Figure 7: Effects of the regulation on worker representation and hourly wages.

Notes: Panel (a) plots the mean residualized rates of worker representation, and Panel (b) plots the mean residualized $\log$ hourly wages for workers in each firm size bin. The dependent variables are residualized with respect to a full set of year, region, and industry fixed effects, and indicators for whether the firm is part of a corporate group and for whether the board represents the entire corporate group. The dashed vertical lines denote the regulation's firm size cut-off of 30 employees. Each graph sets the scale of the y-axis equal to \pm 0.5 standard deviation of the respective variable. The sample used is the RD sample as defined in Section 2, restricted to workers in firms with between 10 and 50 employees in year $t-1$ which remained above or below the cut-off in years $t-1$ and $t-2$. Standard errors are clustered at the firm-level.

significant changes around the cut-off by chance alone is quite large. And for all groups of workers, we can reject the null hypothesis that the OLS and RD estimates are equal, which highlights that selection on unobservables is a key concern when examining the effects of worker representation on corporate boards.

In Appendix Section C, we apply the same RD design to estimate effects on a wide range of firm outcomes. We find no evidence of significant effects of the regulation on measures of firm productivity, assets, investments, or separation rates.

\subsection{Adoption of worker representation}

Taken together, the RD results suggest that there are no significant positive effects of the regulation on the hourly wages of workers. We now complement this reduced form evidence with an event study analysis of workers' compensation in the years around the adoption of worker representation.

\subsubsection{Event study setup and estimation}

Our event study design exploits differences in the timing of adoption of worker representation across firms. This design can be expressed as an event study estimator that compares changes in wages for workers employed in firms adopting worker representation in a given year to changes in wages for workers employed in firms adopting worker representation in later years.

More concretely, for any year $c \in\{2006,2012\}$, let the treatment group consist of all workers 
employed in firms adopting worker representation in that year. The average change in wages between time $c+s$ and the baseline year $c-s^{\prime}$ in the treatment group is denoted by $\mathbb{E}\left[w_{i, c+s}-\right.$ $\left.w_{i, c-s^{\prime}} \mid C_{j(i)}=c\right]$, where $C_{j(i)}$ denotes the year in which the employer $j$ of worker $i$ adopted worker representation. The control group is defined for each cohort $c$ and event time $s$ and consists of all workers in the adoption subsample (as defined in Section 2) who are employed in firms that have not adopted worker representation by year $c+s$ or $c$ (whichever is greater), but that adopt worker representation in a later year within our sample period. The event study estimator between the treatment and control groups is defined as follows (for $s \geq 0$ );

$$
\mathbb{E}\left[w_{i, c+s}-w_{i, c-s^{\prime}} \mid C_{j(i)}=c\right]-\mathbb{E}\left[w_{i, c+s}-w_{i, c-s^{\prime}} \mid C_{j(i)}<c+s\right] .
$$

The event study estimator eliminates unobserved time-invariant individual heterogeneity by comparing workers in firms adopting worker representation before and after the year of adoption, while accounting for year and event-time effects by using workers in firms adopting worker representation in a later year as a control group before worker representation is adopted in their firms. As long as the workers in the treatment and control groups would have had a common trend in wages between years $c-s^{\prime}$ and $c+s$ in the absence of adoption of worker representation, the event study estimator in (4) recovers the average impact of adopting worker representation for cohort $c$ in year $c+s$ for $s \geq 0$.

To implement the event study design, we use the following regression model. For each cohort $c$ and each event time $s$ we create a subsample consisting of workers in firms adopting worker representation in year $c$ (the treatment group) and a control group of workers in firms that have not adopted worker representation by period $c$ or $c+s$, whichever is greater. Using this subsample, we run the regression

$$
w_{i, t}=\alpha_{1}^{c, s}+\alpha_{2}^{c, s} \mathbf{1}\left[C_{j(i)}=c\right]+\pi^{c, s} \mathbf{1}[t=c+s]+\rho^{c, s} \mathbf{1}\left[C_{j(i)}=c, t=c+s\right]+\epsilon_{i, t},
$$

where $\alpha_{1}^{c, s}$ is the control group mean in the baseline year (i.e., $\left.c-s^{\prime}\right), \alpha_{2}^{c, s}$ is a fixed effect for the treated workers (cohort $c$ ), $\pi^{c, s}$ is a time effect for event time $s$, and $\rho^{c, s}$ is an interaction effect. Our parameter of interest $\rho^{c, s}$ measures differences in trends in wages between years $c+s$ and $c-s^{\prime}$ between the treatment and control groups. For $s \geq 0$, this parameter captures the average impact of adopting worker representation for cohort $c$ under the common trends assumption.

\subsubsection{Results}

In Figure 8 we plot the estimated coefficients from equation (5). For each event time $s \in\{c-$ $3, \ldots, c+3\}$, we report an equally weighted average of the cohort-specific coefficients $\rho^{c, s}$, with the baseline event time $c-2$ normalized to zero. ${ }^{13}$ Reassuringly, we find no evidence of differential trends

\footnotetext{
${ }^{13}$ By first estimating the parameter $\rho^{c, s}$ separately for each cohort $c$ and then averaging these parameters across cohorts, we avoid the problems pointed out by Callaway and Sant'Anna (2020) and Sun and Abraham (2020), and we ensure that our event study regressions produce positively-weighted averages of causal effects under the standard common trends assumption.
} 
in wages between current and later adopters in the pre-treatment event times. This is consistent with the wages of workers in the treatment and control groups evolving in the same way across years in the pre-treatment period, providing support for the common trends assumption. There is also no evidence of significant effects of worker representation on wages in the post-treatment event times. These results suggest that incumbent workers in firms adopting worker representation do not experience significant wage gains, relative to their comparison groups, in the years following adoption.

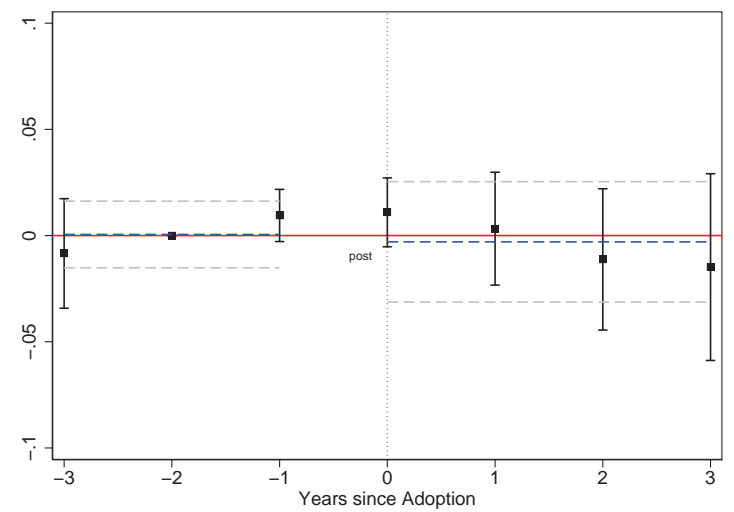

Figure 8: Effects of adoption of worker representation on (log) hourly wages.

Notes: This figure plots the estimated coefficients from equation (5). For each event time $s \in\{c-3, \ldots, c+3\}$, we report an equally weighted average of the cohort-specific coefficients $\rho^{c, s}$, with the baseline event time $c-2$ normalized to zero. Vertical lines represent $95 \%$ confidence intervals constructed using standard errors clustered at the firm-level. The dashed horizontal lines indicate the average treatment effects in the pre- and post-treatment periods, where all time-periods and cohorts are weighted equally. The sample used is the adoption sample as defined in Section 2.

Table 4 reports the average treatment effects in the pre- and post-treatment periods, weighting all cohorts and time periods equally, for the full adoption sample and separately for different groups of workers. There are no significant effects of adoption on hourly wages in the years prior to adoption for any of the subsamples. Moreover, only 1 out of 8 estimated post-treatment effects is significantly different from zero. For most groups, we can reject the null hypothesis that the OLS estimates and the post-treatment event study estimates are equal, suggesting that the OLS estimates of the effects of worker representation on wages are biased.

In Appendix Section C, we apply the same event study design to estimate effects on a wide range of firm outcomes. We find no evidence of significant effects of adoption on measures of firm productivity, employment, investments, or separation rates, but some evidence of a reduction in fixed assets (machines, equipment, etc.). However, given the large number of outcomes, the probability of estimating one significant effect by chance alone is quite large. Thus, we caution about putting too much stock into the estimated reduction in fixed assets. 
Table 4: OLS, reduced form RD, and event study estimates.

\begin{tabular}{|c|c|c|c|c|c|c|c|}
\hline \multirow[b]{4}{*}{ Worker subsample } & \multicolumn{7}{|c|}{ Dependent variable: (log) Hourly wage } \\
\hline & \multicolumn{3}{|c|}{$\mathrm{RD}$} & \multicolumn{4}{|c|}{ Adoption event study } \\
\hline & $(1)$ & $(2)$ & $(3)$ & $(4)$ & $(5)$ & $(6)$ & $(7)$ \\
\hline & OLS & Reduced form & Difference (1) - (2) & OLS & Avg. pre & Avg. post & Difference (4) - (6) \\
\hline \multirow[t]{2}{*}{ All } & 0.038 & -0.009 & 0.047 & 0.047 & 0.001 & -0.003 & 0.049 \\
\hline & $(0.006)$ & $(0.008)$ & $(0.011)$ & $(0.009)$ & $(0.008)$ & $(0.014)$ & $(0.018)$ \\
\hline \multicolumn{8}{|l|}{ Demographics } \\
\hline \multirow[t]{2}{*}{ Male } & 0.038 & -0.013 & 0.051 & 0.043 & -0.000 & 0.003 & 0.039 \\
\hline & $(0.006)$ & $(0.009)$ & $(0.004)$ & $(0.009)$ & $(0.009)$ & $(0.014)$ & $(0.019)$ \\
\hline \multirow[t]{2}{*}{ Female } & 0.048 & 0.009 & 0.039 & 0.055 & 0.001 & -0.007 & 0.062 \\
\hline & $(0.007)$ & $(0.010)$ & $(0.002)$ & $(0.010)$ & $(0.007)$ & $(0.018)$ & $(0.019)$ \\
\hline \multirow[t]{2}{*}{ Unionized } & 0.034 & -0.024 & 0.057 & 0.032 & -0.008 & -0.018 & 0.050 \\
\hline & $(0.006)$ & $(0.009)$ & $(0.000)$ & $(0.009)$ & $(0.011)$ & $(0.017)$ & $(0.020)$ \\
\hline \multirow[t]{2}{*}{ Non-unionized } & 0.053 & 0.004 & 0.049 & 0.101 & 0.005 & 0.003 & 0.098 \\
\hline & $(0.007)$ & $(0.009)$ & $(0.016)$ & $(0.010)$ & $(0.006)$ & $(0.015)$ & $(0.015)$ \\
\hline \multicolumn{8}{|l|}{ Education } \\
\hline \multirow[t]{2}{*}{ Low-skilled } & 0.025 & -0.010 & 0.034 & 0.031 & 0.007 & -0.002 & 0.033 \\
\hline & $(0.006)$ & $(0.008)$ & $(0.014)$ & $(0.008)$ & $(0.007)$ & $(0.014)$ & $(0.016)$ \\
\hline \multirow[t]{2}{*}{ High-skilled } & 0.058 & -0.007 & 0.065 & 0.074 & 0.008 & 0.042 & 0.032 \\
\hline & $(0.007)$ & $(0.012)$ & $(0.000)$ & $(0.011)$ & $(0.008)$ & $(0.015)$ & $(0.021)$ \\
\hline \multicolumn{8}{|l|}{ Occupation } \\
\hline \multirow[t]{2}{*}{ Blue collar } & 0.034 & -0.013 & 0.047 & 0.038 & 0.004 & -0.021 & 0.059 \\
\hline & $(0.007)$ & $(0.010)$ & $(0.006)$ & $(0.010)$ & $(0.009)$ & $(0.016)$ & $(0.018)$ \\
\hline \multirow[t]{2}{*}{ Manager } & 0.069 & 0.014 & 0.056 & 0.135 & 0.005 & -0.011 & 0.146 \\
\hline & $(0.009)$ & $(0.013)$ & $(0.015)$ & $(0.012)$ & $(0.010)$ & $(0.021)$ & $(0.022)$ \\
\hline
\end{tabular}

Notes: OLS regressions control for a full set of year, region, and industry indicators, whether the firm is publicly listed, whether the firm is part of a corporate group, and whether the board represents the entire corporate group. The worker characteristics are defined in Appendix Table A.1. In the RD panel, the sample used is the RD sample as defined in Section 2, restricted to workers in firms with between 10 and 50 employees in year $t-1$ which remained above or below the cut-off in years $t-1$ and $t-2$. Column (2) reports estimates of the coefficient $\lambda$ from equation (3). In the adoption panel, the OLS estimate is estimated using the stayers subsample and the adoption event study estimates are estimated using the adoption subsample, as defined in Section 2, and the comparison groups are as defined in the text. Columns (5) and (6) report averages of the cohort-specific coefficients $\rho^{c, s}$ from equation (5) for the pre- and post-treatment periods, respectively, where all time-periods and cohorts are weighted equally. Standard errors are clustered at the firm-level in all columns. Standard errors of the differences in Columns 3 and 7 are estimated using 500 block bootstrap draws in which the block is taken to be the firm. 


\section{$6 \quad$ Interpreting the results}

In Section 4, we reported results showing significant but modest causal impacts on wages of working in a firm with worker representation. The results reported in Section 5, however, suggest that the wage impacts of working in a firm with worker representation are not driven by worker representation per se, but rather by other factors that are correlated both with worker representation and with worker compensation. In this section, we focus on two observable factors that are strongly correlated with worker representation - firm size and the share of unionized workers - and investigate whether these two factors can help reconcile the results in Sections 4 and 5.

To this end, we first return to our analysis of job switchers from Section 4.1, and estimate wage premia associated with working in larger or more unionized firms. Similarly, we revisit the pass-through analysis from Section 4.2, and investigate the extent to which the pass-through of value added shocks to wages depends on firm size or on the share of unionized workers. As a last step, we control for these characteristics in both the job switchers and the pass-through analyses

to examine whether the difference in worker compensation between firms with and without worker representation can be explained by these two characteristics.

\subsection{Worker representation wage premium revisited}

We begin by estimating the causal impact of working in a large or unionized firm on hourly wages. To this end, we return to our analysis of job movers and use a similar differences-in-differences setup, which we implement using the following regression model:

$$
w_{i, s}=\alpha_{i}+\pi_{s}+\sum_{k=-3}^{3} \tau_{k} \mathbf{1}[s=k, G(i)=1]+\epsilon_{i, s},
$$

where $s$ denotes year relative to when the worker switched jobs, $\alpha_{i}$ is a worker fixed effect, $\pi_{s}$ denotes time effects, and $G(i)$ is an indicator for whether worker $i$ switched to a larger (or unionized) firm. The treatment and comparison groups are constructed in the same way as in Section 4.1: The treatment group includes workers switching from a smaller (non-unionized) firm to a larger (unionized) firm, while the comparison group includes workers switching between two smaller (nonunionized) firms. Including a comparison group allows us to look within workers over time while eliminating changes in wages common to all workers moving from the same firm in the same year. To make sure the firm characteristics are predetermined relative to the year of the move, we measure the firm size and unionization rate of the origin and destination firms in year $s=-2$. We define a large firm as a firm with more than 50 employees, and a unionized firm as a firm in which more than $25 \%$ of workers are unionized. The coefficients of interest $\tau_{k}$ capture the wage impact of moving to a larger (or unionized) firm, measured $k$ years before or after the move.

Panel (a) of Figure 9 plots the DiD estimates from the specification in equation (6) of the wage impacts of moving from a smaller to a larger firm. The dotted line plots the average wage impact in 
the post-treatment period $(k>0)$. Moving to a larger firm increases hourly wages by about $5 \% .{ }^{14}$ Similarly, Panel (b) shows that moving to a unionized firm increases hourly wages by about $3 \%$. In both panels, we find no differences in wage growth between the treatment and comparison groups in the years before switching jobs, lending credibility to our identifying assumption of parallel trends between the two groups of workers. We therefore conclude that working in a larger or more unionized firm has a positive and significant causal impact on wages.

Figure 9: Wage premia of observed firm characteristics correlated with worker representation.

(a) Moving into a large firm.

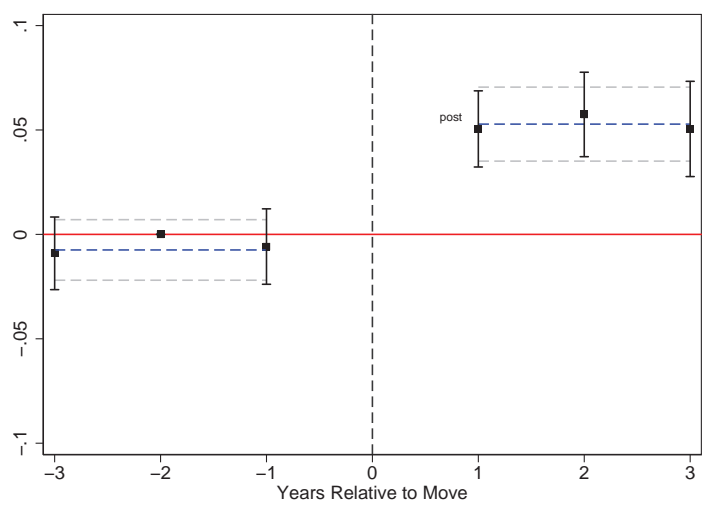

(b) Moving into a unionized firm.

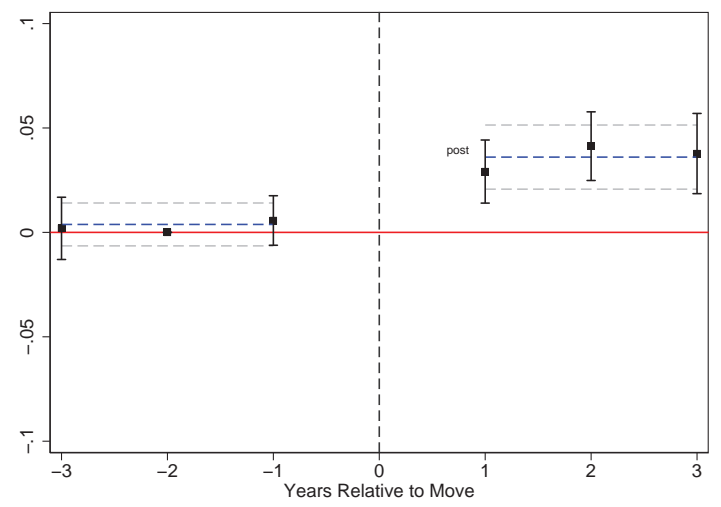

Notes: These figures plot the estimated $\tau_{k}$ coefficients (along with 95\% confidence intervals) from the specification in equation (6), for $k \in\{-3, \ldots, 3\}$. The parameter $\tau^{\text {post }}$ indicates the impact in the post-treatment period $(k>0)$. In Panel (a), the treatment group includes workers switching from a firm with fewer than 50 employees to a firm with more than 50 employees, while the comparison group includes workers switching between two firms with fewer than 50 employees. In Panel (b), the treatment group includes workers switching from a firm in which less than $25 \%$ of workers are unionized to a firm in which more than $25 \%$ of workers are unionized, while the comparison group includes workers switching between two firms in which less than $25 \%$ of workers are unionized. In both figures, we restrict to firms with at least one worker in both the treatment and comparison groups. Standard errors are clustered at the firm-level.

Having documented causal impacts on wages of working in larger or more unionized firms, a natural next question is whether these two characteristics can help explain the wage impact of working in a firm with worker representation. In the first panel of Table 5, we therefore investigate the sensitivity of the estimated worker representation wage premium to fixing firm size and the share of unionized workers. Column 1 reports the $4 \%$ wage impact of moving to a firm with worker representation (as reported in Column 1 of Table 2 in Section 4.1). In Column 2, we control for the size of the destination firm (in bins) interacted with an indicator for the post-treatment period, while the specification in Column 3 also controls for unionization rate interacted with an indicator for the post-treatment period. ${ }^{15}$ Adding these controls reduces the coefficient of interest from 4.3

\footnotetext{
${ }^{14}$ Differences in wages across firms of different sizes, controlling for differences in worker quality, have been documented before; see e.g. Abowd et al. (1999).

${ }^{15}$ Controls for firm size and unionization rate in levels are subsumed by the worker fixed effects, since both variables are measured in year $s=-2$.
} 
to $1.6 \%$, suggesting that firm size and the share of unionized workers can account for more than $60 \%$ of the estimated worker representation wage premium. In Column 4 , we also add controls for a range of other observable firm and worker characteristics, such as industry and the share of workers with a college degree, all interacted with an indicator for the post-treatment period. With the full set of controls, the estimated worker representation wage premium is further reduced to a non-significant $0.8 \%$.

\subsection{Pass-through analysis revisited}

Next, we return to our analysis of the pass-through of firm shocks to the wages of incumbent workers. As before, we focus on the stayers subsample and estimate the following specification separately for workers in firms with different observed firm characteristics:

$$
w_{i, t}=\phi_{j(i)}+\gamma y_{j(i), t}+X_{i, t}^{\prime} \delta+\epsilon_{i, t}
$$

where $y_{j(i), t}$ is the $(\log )$ value added of firm $j$ in year $t, \phi_{j(i)}$ is a fixed effect for worker $i$ if she works in firm $j$, and $X_{i, t}$ includes a full set of (two-digit) industry-by-year indicators and a cubic polynomial in age. When equation (7) is estimated separately for workers in firms with different observed firm characteristics, the parameter of interest $\gamma$ measures the pass-through rate of an idiosyncratic value added shock to the wages of incumbent workers in firms with different observed characteristics, i.e. large vs small and unionized vs non-unionized.

Figure 10 plots the estimated pass-through rates by firm size (Panel (a)) and by the share of unionized workers (Panel (b)). The estimates reported in Panel (a) show stark differences in the sensitivity of wages to fluctuations in firm performance between smaller and larger firms: In firms with fewer than 30 employees, a $10 \%$ decrease in firm value added is associated with a $1 \%$ decrease in wages. By contrast, workers in firms with more than 200 employees only experience a $0.2 \%$ decrease in wages in response to a $10 \%$ decrease in firm value added. Similarly, the estimates reported in Panel (b) show that the pass-through rates are also declining in the firm unionization rate. We therefore conclude that the degree of wage insurance differs systematically across firms according to both firm size and unionization.

In Panel B of Table 5, we investigate the sensitivity of the estimated difference in pass-through rates between workers in firms with and without representation to controlling for firm size and the share of unionized workers. Column 1 presents the estimate from Section 4.2, showing that the decrease in wages in response to a $10 \%$ decrease in value added is 0.6 percentage points lower for workers in firms with worker representation than for workers in firms without representation. In Column 2, we control for the differential pass-through in larger versus smaller firms by interacting $(\log )$ value added with firm size (binned), while the specification in Column 3 also controls for the differential pass-through in unionized versus non-unionized firms by interacting (log) value added with firm size (binned). ${ }^{16}$ Adding these controls reduces the difference in pass-through rates

\footnotetext{
${ }^{16}$ Controls for firm size and unionization rate in levels are subsumed by the worker-firm fixed effects $\phi_{j(i)}$, since
} 
Figure 10: Heterogeneity in pass-through rates.

(a) Firm size

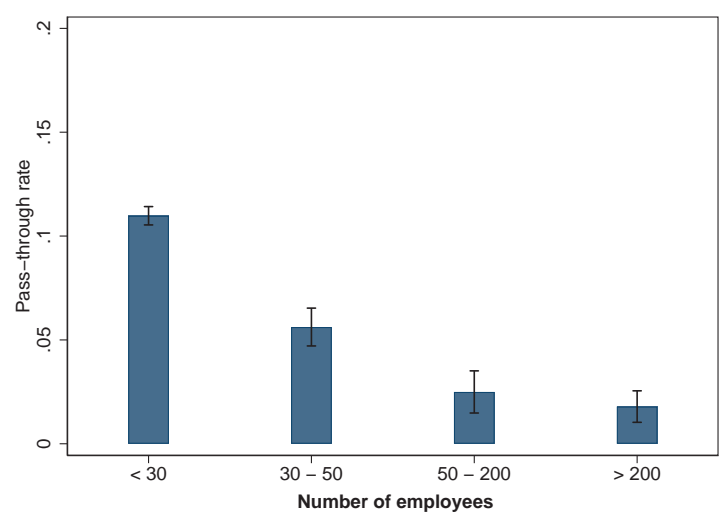

(b) Unionization rate

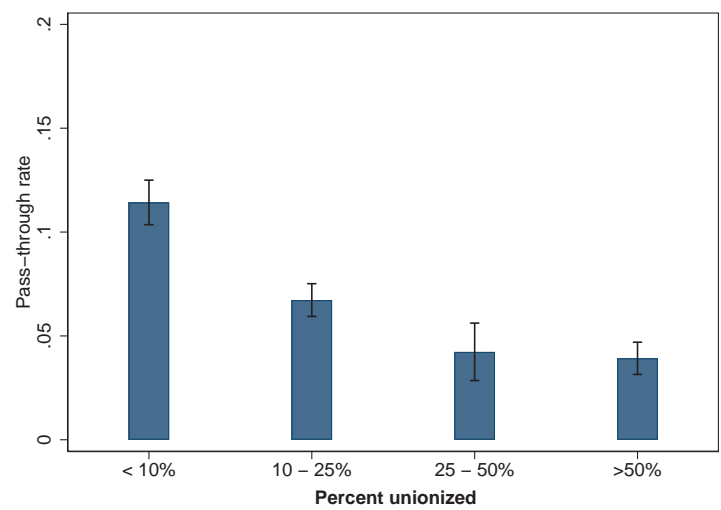

Notes: This figure shows estimated pass-through rates (along with 95\% confidence intervals) from equation (7) estimated separately for workers in firms of different sizes (Panel (a)) and for workers in firms with different unionization rates (Panel (b)). The sample is restricted to the stayers subsample as defined in Section 2. The number of employees and the unionization rate of each firm are measured in the first year the worker is employed by the firm. Standard errors are clustered at the firm-level.

between workers in firms with and without representation from 0.64 to 0.15 percentage points. ${ }^{17}$ This suggests that firm size and the share of unionized workers can account for almost $80 \%$ of the estimated difference in pass-through rates between workers in firms with and without representation. In Column 4, we also add controls for a range of other observable firm and worker characteristics. With the full set of controls, the estimated difference in pass-through rates between workers in firms with and without representation is further reduced to 0.07 percentage points.

both variables are measured in the first year the worker is employed by the firm.

${ }^{17}$ The reason why the point estimate in Column 1 of Panel B (-0.064) does not exactly match the point estimate reported in Column 3 of Table 3 in Section $4.2(-0.066)$ is that the sample used for Panel B of Table 5 is restricted to observations for which we observe the full set of controls, to ensure that the sample remains unchanged across columns. 
Table 5: Controlling for firm characteristics correlated with worker representation.

Dependent variable: (log) Hourly wage

(1)

(4)

Panel A. Worker representation wage premium

\begin{tabular}{ccccc}
\hline Post $\times$ Into-treatment & 0.043 & 0.018 & 0.016 & 0.008 \\
& $(0.005)$ & $(0.007)$ & $(0.007)$ & $(0.007)$
\end{tabular}

Panel B. Pass-through rate

\begin{tabular}{lcccc}
\hline Worker representation $\times(\log )$ Value added & -0.064 & -0.020 & -0.015 & -0.007 \\
& $(0.005)$ & $(0.006)$ & $(0.005)$ & $(0.005)$ \\
& & & & \\
\hline Controls & & & & \\
Baseline & $\mathrm{x}$ & $\mathrm{x}$ & $\mathrm{x}$ & $\mathrm{x}$ \\
Firm size & & $\mathrm{x}$ & $\mathrm{x}$ & $\mathrm{x}$ \\
Unionization rate & & & $\mathrm{x}$ & $\mathrm{x}$ \\
Other firm characteristics & & & $\mathrm{x}$ \\
\hline
\end{tabular}

Notes: This table shows the wage impacts of worker representation after controlling for firm characteristics that are correlated with worker representation. Panel A reports estimated worker representation wage premia from a version of equation (1) where the period-specific indicators $\mathbf{1}[s=k, G(i)=1]$ and the corresponding coefficients $\tau_{k}$ are replaced with a single post-treatment indicator $\mathbf{1}[k>0, G(i)=1]$ and a single coefficient $\tau^{\text {post }}$. Column 1 controls for worker fixed effects and an indicator for the post-treatment period. Column 2 adds an indicator for whether the worker moved to a large firm interacted with the post-treatment indicator. Column 3 adds an indicator for whether the worker moved to a unionized firm interacted with the post-treatment indicator. Column 4 controls for other observed firm characteristics of the destination firm interacted with the post-treatment indicator. In all columns, the sample is restricted to the observations in the movers subsample for which we observe all firm characteristics at both the origin and destination firms. Panel B reports estimated differences in the pass-through of (log) value added to wages between firms with and without worker representation, where the pass-through rates for each group of firms are obtained from separate estimations of equation (2). Column 1 includes worker-firm and industry-by-year fixed effects and a cubic polynomial in worker age. Column 2 controls for the differential pass-through in larger versus smaller firms by interacting firm size (binned) with (log) value added. Column 3 additionally controls for the firm unionization rate (binned) interacted with (log) value added. Column 4 controls for the differential pass-through rate associated with other observed firm characteristics by interacting each characteristic with (log) value added. In both panels, other observed firm characteristics include whether the firm is publicly listed, whether the firm is part of a corporate group, and whether the board represents the entire corporate group, industry, firm age (bins), labor share, capital to labor ratio, share of workers with a college degree, the average age of workers, share of workers who are male, and the share of workers who are immigrants. We binarize all continuous controls at the median of the distribution. Standard errors are clustered at the firm-level in both panels. 


\section{Conclusion}

Do employees benefit from worker representation on corporate boards? Economists and policymakers are keenly interested in this question - especially lately, as worker representation is widely promoted as an important way to ensure the interests and views of the workers. The goal of our paper was to empirically investigate this question, applying a variety of research designs to administrative data from Norway. We found that a worker is paid more and faces less earnings risk if she gets a job in a firm with worker representation on the corporate board. However, these gains in wages and declines in earnings risk are not caused by worker representation per se. Instead, the wage premium and reduced earnings risk reflect that firms with worker representation are likely to be larger and unionized, and that larger and unionized firms tend to both pay a premium and provide better insurance to workers against fluctuations in firm performance. Conditional on the firm's size and unionization rate, worker representation has little if any effect. Taken together, these findings suggest that while workers may indeed benefit from being employed in firms with worker representation, they would not benefit from legislation mandating worker representation on corporate boards. One possible explanation for this absence of significant effects of adopting worker representation on the corporate board is that minority positions on corporate boards have little influence on the overall strategy and pay schemes of the firm. This would be consistent with the findings of Bertrand et al. (2019), who document that gender quotas on corporate boards had very little discernible impact on women in business beyond its direct effect on the women who made it into boardrooms.

A natural question is whether these findings are specific to the Norwegian setting or generalize more broadly. To shed light of this difficult question, it is useful to compare our findings to those reported in previous work from the German setting (see e.g. Gorton and Schmid, 2004; Jäger, Schoefer and Heining (2021)). Germany has a two-tiered board system, with both a supervisory board and an executive board. Norway, on the other hand, has the same system as in the US, the UK, and several other European countries, with a single-tiered board of directors. Worker representatives on the executive boards of Norwegian corporations are likely to be more directly involved in day-to-day operations than those on the supervisory boards of German corporations. Despite the differences in institutions, however, our findings are broadly consistent with the results from the German setting. This indicates that the conclusion about the absence of wage impacts of worker representation may indeed generalize across shared governance systems that differ markedly in the degree to which workers are given authority in the corporate decision-making. 


\section{References}

Abowd, John M, Francis Kramarz, and David N Margolis, "High wage workers and high wage firms," Econometrica, 1999, 67 (2), 251-333.

Adams, Renée B, Benjamin E Hermalin, and Michael S Weisbach, "The role of boards of directors in corporate governance: A conceptual framework and survey," Journal of Economic Literature, 2010, 48 (1), 58-107.

Ahern, Kenneth R and Amy K Dittmar, "The changing of the boards: The impact on firm valuation of mandated female board representation," The Quarterly Journal of Economics, 2012, $127(1), 137-197$.

Balke, Neele and Thibaut Lamadon, "Productivity Shocks, Long-Term Contracts and Earnings Dynamics," NBER Working Paper 28060, November 2020.

Bertrand, Marianne, Sandra E Black, Sissel Jensen, and Adriana Lleras-Muney, "Breaking the glass ceiling? The effect of board quotas on female labour market outcomes in Norway," The Review of Economic Studies, 2019, 86 (1), 191-239.

Black, Bernard and Woochan Kim, "The effect of board structure on firm value: A multiple identification strategies approach using Korean data," Journal of Financial Economics, 2012, 104 (1), 203-226.

Callaway, Brantly and Pedro H. C. Sant'Anna, "Difference-in-Differences with Multiple Time Periods," Working Paper, 2020.

Card, David, "The effect of unions on the structure of wages: A longitudinal analysis," Econometrica, 1996, pp. 957-979.

Dale-Olsen, Harald, Marte Strøm, Kjersti Misje Østbakken, and Erling Barth, "Avtaleformer, lønnsvekst og lønnsspredning," Rapport-Institutt for samfunnsforskning, 2018.

DiNardo, John and David S. Lee, "Economic Impacts of New Unionization on Private Sector Employers: 1984-2001," The Quarterly Journal of Economics, 2004, 119 (4), 1383-1441.

_, Nicole M. Fortin, and Thomas Lemieux, "Labor Market Institutions and the Distribution of Wages, 1973-1992: A Semiparametric Approach," Econometrica, 1996, 64 (5), 1001.

Gorton, Gary and Frank A Schmid, "Capital, labor, and the firm: A study of German codetermination," Journal of the European Economic Association, 2004, 2 (5), 863-905.

Guiso, Luigi, Luigi Pistaferri, and Fabiano Schivardi, "Insurance within the firm," Journal of Political Economy, 2005, 113 (5), 1054-1087. 
Harju, Jarkko, Simon Jaeger, and Benjamin Schoefer, "Voice at Work," Working paper, 2021.

Jäger, Simon, Benjamin Schoefer, and Jörg Heining, "Labor in the Boardroom," The Quarterly Journal of Economics, 2021, 136 (2), 669-725.

Juhn, Chinhui, Kristin McCue, Holly Monti, and Brooks Pierce, "Firm Performance and the Volatility of Worker Earnings," Journal of Labor Economics, 2018, 36 (1), 99-131.

Kim, E Han, Ernst Maug, and Christoph Schneider, "Labor representation in governance as an insurance mechanism," Review of Finance, 2018, 22 (4), 1251-1289.

Lee, David S. and Thomas Lemieux, "Regression Discontinuity Designs in Economics," Journal of Economic Literature, 2010, 48 (2), 281-355.

Lemieux, Thomas, "Unions and Wage Inequality in Canada and the United States," in "Small Differences That Matter: Labor Markets and Income Maintenance in Canada and the United States," University of Chicago Press, 1993, pp. 69-108.

Lin, Chen, Thomas Schmid, and Yuhai Xuan, "Employee representation and financial leverage," Journal of Financial Economics, 2018, 127 (2), 303-324.

Matsa, David A and Amalia R Miller, "A female style in corporate leadership? Evidence from quotas," American Economic Journal: Applied Economics, 2013, 5 (3), 136-69.

McCrary, Justin, "Manipulation of the running variable in the regression discontinuity design: A density test," Journal of Econometrics, 2008, 142 (2), 698-714.

Redeker, Nils, "The Politics of Stashing Wealth: The Demise of Labor Power and the Global Rise of Corporate Savings," Working Paper, 2019.

Sun, Liyang and Sarah Abraham, "Estimating Dynamic Treatment Effects in Event Studies with Heterogeneous Treatment Effects," Working paper, 2020. 


\section{A Data}

Table A.1: Variable definitions

\begin{tabular}{|c|c|}
\hline Variable & Description \\
\hline Labor market outcomes & Source: Tax Records and the Norwegian Labor and Welfare Administration \\
\hline Earnings & $\begin{array}{l}\text { Annual pre-tax labor earnings measured at the worker-firm level. Earnings include fixed salary, bonus, } \\
\text { overtime, and vacation and severance pay, but exclude sickness benefits. }\end{array}$ \\
\hline Hours worked & Number of contracted hours worked each calendar year. \\
\hline Hourly wage & Annual earnings divided by hours worked. Outliers below the 5 th percentile are winsorized. \\
\hline Firm accounts & Source: The Register of Company Accounts \\
\hline Revenues & Total annual sales by each firm in a given year. \\
\hline Cost of inputs & Cost of materials and intermediate inputs for each firm in a given year. \\
\hline Value added & Revenues minus cost of inputs. \\
\hline Labor share & Annual wage bill divided by value added. \\
\hline Capital to labor ratio & Total firm assets divided by annual wage bill. \\
\hline Corporate boards & Source: The Register of Legal Entities \\
\hline Director's role & Indicates each director's role on the board, e.g. chair vs regular directors. \\
\hline Elected by & Indicates whether each director is elected by and among the employees or by shareholders. \\
\hline Level of representation & Indicates whether the board governs a single firm or a corporate group with several firms. \\
\hline Worker characteristics & Source: National Education Database, Central Population Register, and Tax Returns \\
\hline Age & Age in years, measured at the beginning of each year. \\
\hline Male & Indicator variable for male workers. \\
\hline Tenure & Tenure with the current firm in years, measured at the beginning of each year. \\
\hline Immigrant & Indicator for individuals having a country of birth other than Norway. \\
\hline Unionized & Indicator for union membership based on union membership fee deductions in the tax returns. \\
\hline Years of education & Number of years corresponding to highest completed level of education. \\
\hline Low-skilled & Indicator for individuals without a college degree. \\
\hline High-skilled & Indicator for individuals with a college degree. \\
\hline Blue collar & $\begin{array}{l}\text { Indicator for individuals having a blue collar occupation based on the first digit of the International } \\
\text { Standard Classification of Occupations (ISCO-88) codes. }\end{array}$ \\
\hline Manager & Indicator for individual having a job with primarily managerial duties based on 3-digit ISCO-88 codes. \\
\hline Firm characteristics & $\begin{array}{l}\text { Source: Central Register of Establishments and Enterprises and the Norwegian Labor and Welfare } \\
\text { Administration. }\end{array}$ \\
\hline Firm size & $\begin{array}{l}\text { Number of employees measured as the number of registered workers at the beginning of each year, } \\
\text { part-time workers are counted as } 0.5\end{array}$ \\
\hline Firm age & Number of years since establishment. \\
\hline Region & Region indicators based on 4-digit code for the municipality in which a firm is located in a given year. \\
\hline Industry & $\begin{array}{l}\text { 2-digit code classifying a firm's main activity according to the Nomenclature of Economic Activities (first } \\
\text { two digits of NACE2007) system. }\end{array}$ \\
\hline Corporate group & Indicator for firms that are part of a corporate group. \\
\hline Board of corporate group & Indicator for firms that are the parent firm within a corporate group. \\
\hline Publicly listed & Indicator for publicly listed firms. \\
\hline Average age & The average age of employed workers measured at the beginning of each year. \\
\hline Share of male workers & Share of employed workers who are male. \\
\hline Share of immigrant workers & Share of employed workers having a country of birth other than Norway. \\
\hline Share of skilled workers & Share of employed workers with a college degree. \\
\hline Unionization rate & Share of employed workers deducting union membership fees in the tax returns. \\
\hline
\end{tabular}




\section{B Additional Figures and Tables}

Figure B.1: Fraction of explained variability in worker representation attributable to each predetermined firm characteristic.

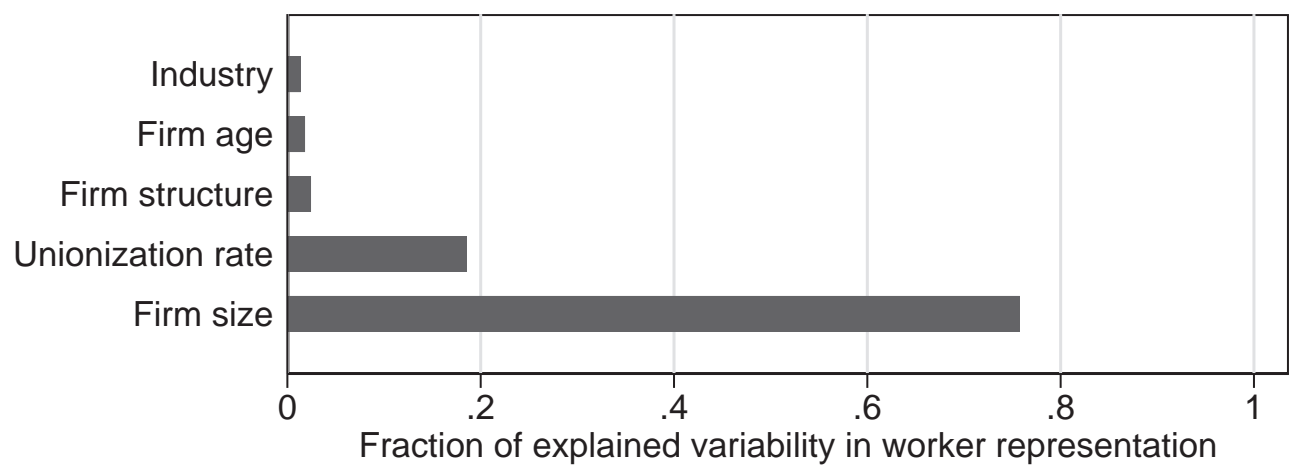

Notes: This figure plots the partial $R^{2}$ s of each firm characteristic from a regression of an indicator for whether the firm has at least one worker representative on the corporate board on the firm's industry, age, unionization rate, size, whether the firm is publicly listed, whether the firm is part of a corporate group, and whether the board represents the entire corporate group. The label "Firm structure" refers to the three last mentioned characteristics. The partial $R^{2}$ s are normalized to sum to one such that each of the reported values can be directly interpreted as the share of explained variability that is attributable to an observable aspect of the firm. 


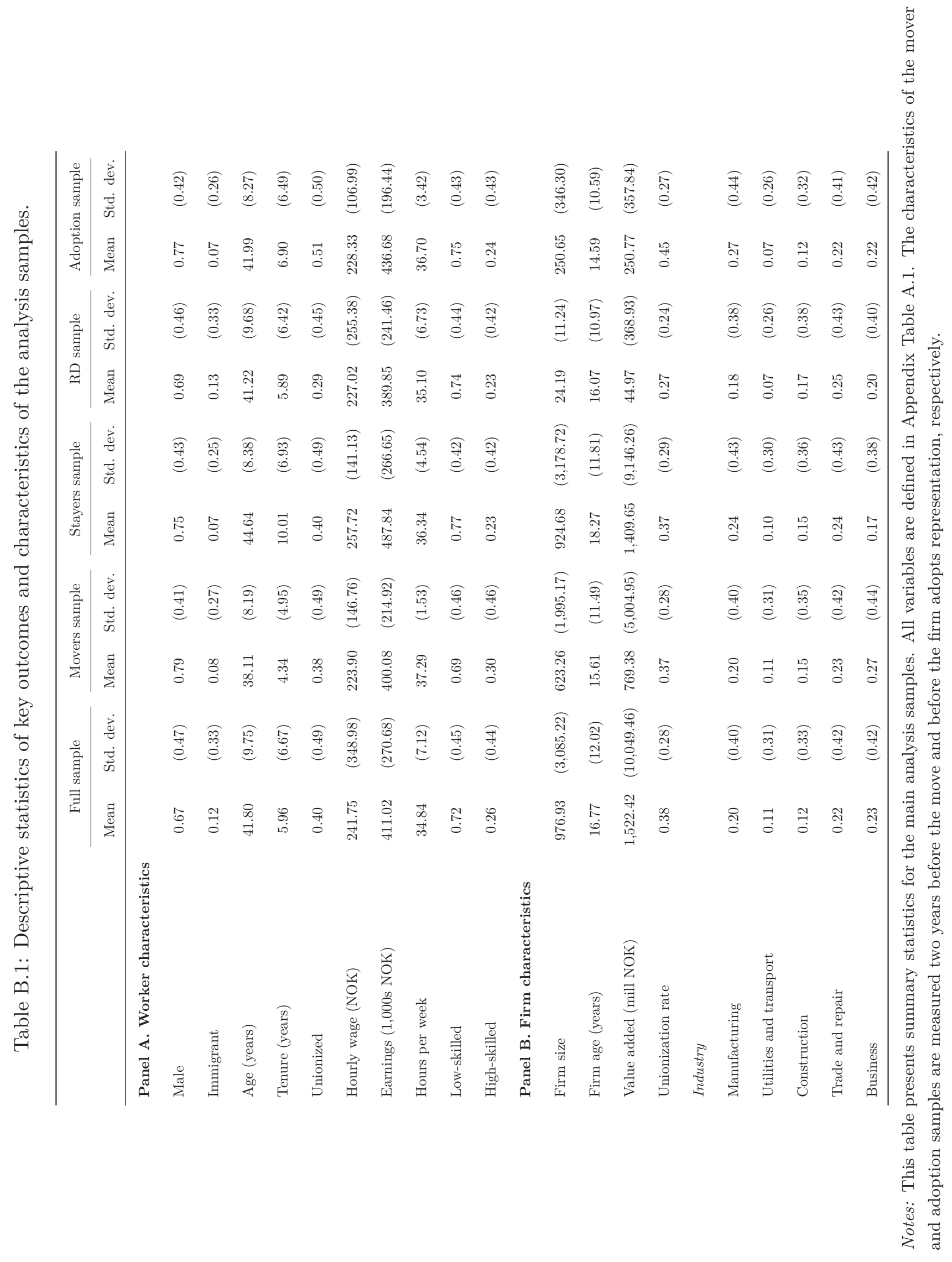


Figure B.2: Sensitivity of the reduced form RD estimate to the bandwidth selection.

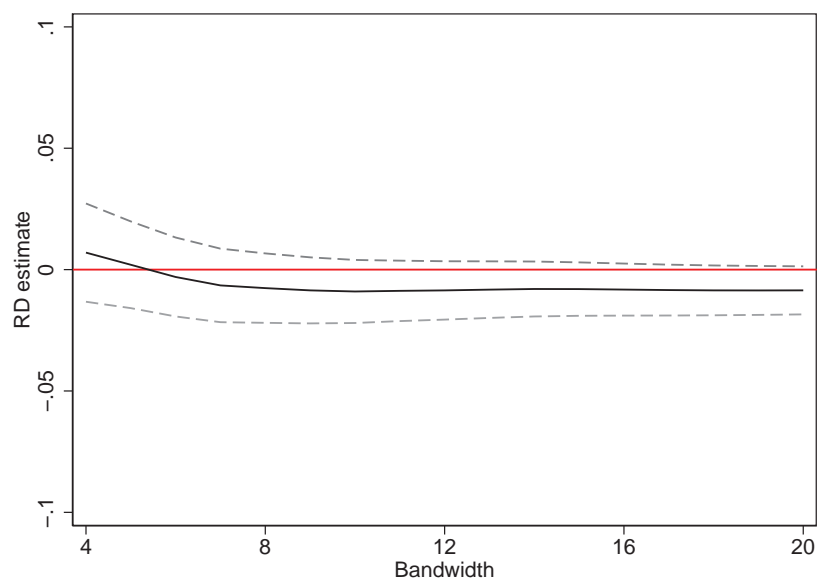

Notes: This figure plots the estimated reduced form effects of the regulation on hourly wages from equation (3) for different choices of bandwidth. The dashed gray lines indicate $90 \%$ confidence intervals. The sample used is the RD sample as defined in Section 2, restricted to workers in firms with between 10 and 50 employees in year $t-1$ which remained above or below the cut-off in years $t-1$ and $t-2$. 


\section{Effects on firm outcomes}

In Section 5, we found no evidence of significant effects on wages of adopting worker representation on the corporate board of a given firm. And in Section 6, we demonstrated that the gains from working in a firm with worker representation disappear once one accounts for differences in firm size and the share of unionized workers. While these findings suggest that workers would not benefit - in terms of higher wages or lower earnings risk - from legislation mandating worker representation on corporate boards, they do not rule out effects on other measures of firm quality and firm performance. Therefore, we now return to our analysis of the causal effect of adopting worker representation on the corporate board of a given firm and estimate effects on a range of firm outcomes.

To this end, we first return to our RD design and estimate discontinuities in firm outcomes at the firm size cut-off. Figure B.3 illustrates the effect of the regulation on firm outcomes and is constructed in the exact same way as Figure 7. Each outcome is residualized with respect to a set of pre-determined firm characteristics, including a full set of year, industry, and region fixed effects, whether the firm is publicly listed, whether the firm is part of a corporate group, and whether the board represents the entire corporate group. We plot the mean of residualized outcomes in each firm-size bin and the estimated means using local linear regressions on each side of the cut-off, and standardize the scale of the y-axis to \pm 0.5 standard deviation of the outcome. There are no visible discontinuities in measures of firm productivity, assets, and investments, nor on employment, the share of part-time workers, and separation rates.

Columns (1) and (2) of Table B.2 present OLS and reduced form RD estimates for all firm outcomes. In the OLS specification, we regress each firm outcome on an indicator for whether the firm has worker representation, controlling for pre-determined firm characteristics. Firms with worker representation are generally larger, have lower separation rates, and employ fewer part-time workers. In the reduced form RD specification, we estimate equation (3) at the firm-level for each firm outcome. In contrast to the OLS estimates, the reduced form RD estimates are all close to zero and insignificant.

We next return to our event study analysis around the adoption of worker representation. Analogous to our estimates of wage effects, the event study framework compares changes in outcomes for firms adopting worker representation in a given year to changes in outcomes for firms adopting worker representation in later years. For each cohort $c$ and each event time $s$ we create a subsample consisting of firms adopting worker representation in year $c$ (the treatment group) and a control group of firms that have not adopted worker representation by period $c$ or $c+s$, whichever is greater. Using this subsample, we run the regression

$$
y_{j, t}=\alpha_{1}^{c, s}+\alpha_{2}^{c, s} \mathbf{1}\left[C_{j}=c\right]+\pi^{c, s} \mathbf{1}[t=c+s]+\rho^{c, s} \mathbf{1}\left[C_{j}=c, t=c+s\right]+\epsilon_{j, t},
$$

where $y_{j, t}$ denotes a firm outcome, $\alpha_{1}^{c, s}$ is the control group mean in the baseline year (i.e., $c-s^{\prime}$ ),

$\alpha_{2}^{c, s}$ is a fixed effect for the treated firms (cohort $\left.c\right), \pi^{c, s}$ is a time effect for event time $s$, and $\rho^{c, s}$ 
Figure B.3: Effects of the regulation on firm outcomes.

(a) $(\log )$ Value added

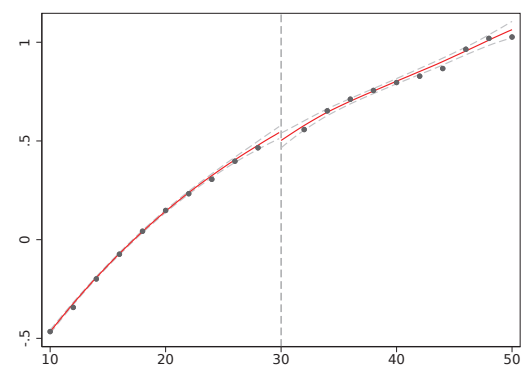

(d) $(\log )$ Employment

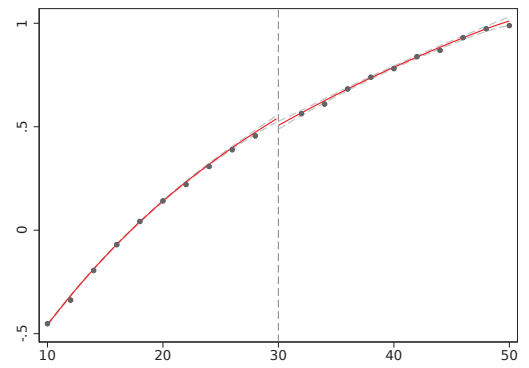

(b) (log) Fixed assets

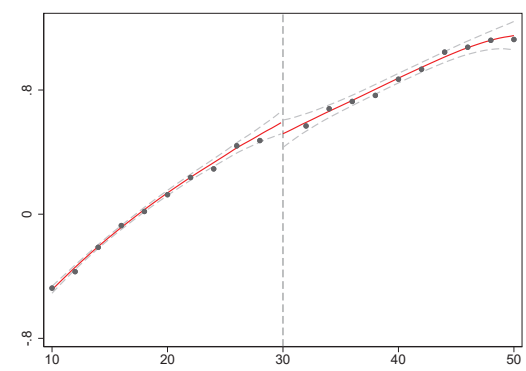

(e) Part-time share

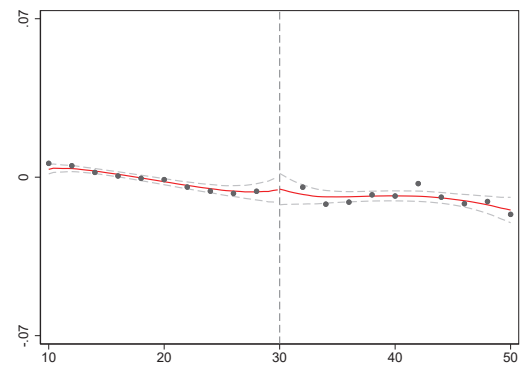

(c) Investment

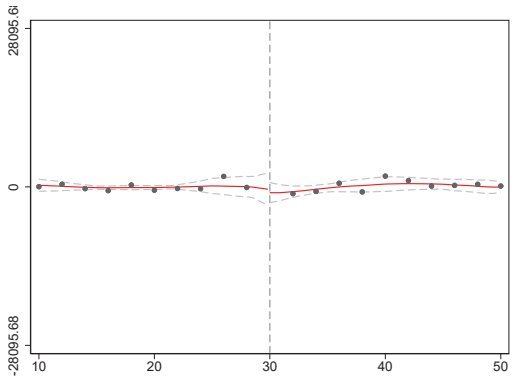

(f) Separation rate

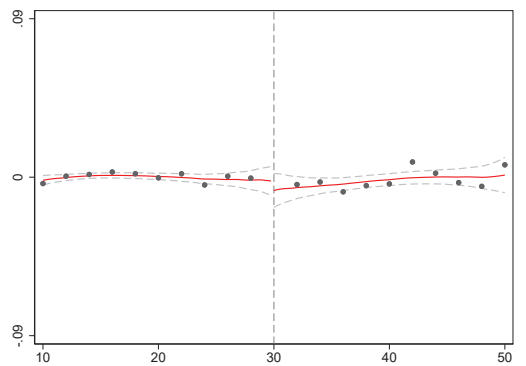

Notes: The dependent variables are residualized with respect to a full set of year, region, and industry fixed effects, and indicators for whether the firm is part of a corporate group and for whether the board represents the entire corporate group. The dashed vertical lines denote the regulation's firm size cut-off of 30 employees. Each graph sets the scale of the $y$-axis equal to \pm 0.5 standard deviation of the respective variable. The sample used is the RD sample as defined in Section 2, restricted to firms with between 10 and 50 employees in year $t-1$ which remained above or below the cut-off in years $t-1$ and $t-2$. Standard errors are clustered at the firm-level.

is an interaction effect. Our parameter of interest $\rho^{c, s}$ measures differences in trends in outcomes between years $c+s$ and $c-s^{\prime}$ between the treatment and control groups. For $s \geq 0$, this parameter captures the average impact of adopting worker representation for cohort $c$ under the common trends assumption.

Columns (5) and (6) of Table B.2 report the average treatment effects in the pre- and posttreatment periods, weighting all cohorts and time periods equally. For nearly all outcomes, we find no evidence of significant changes in firm outcomes in the years following adoption of worker representation. ${ }^{18}$ The only exception is fixed assets where firms adopting worker representation experience a decrease in the post-period, on average, relative to the control group. In contrast, Jäger et al. (2021) find that worker representation increased capital formation. However, given the large number of outcomes we examine, the probability of observing at least one significant estimate by chance is quite large. Therefore, we caution against putting too much stock in the estimated reduction in fixed assets.

\footnotetext{
${ }^{18}$ There is also little evidence of significant changes in firm outcomes when estimating at the worker-level.
} 
Table B.2: OLS and reduced form estimates of the effect of the regulation and worker representation on firm outcomes.

\begin{tabular}{|c|c|c|c|c|c|c|c|}
\hline \multirow[b]{3}{*}{ Firm outcome } & \multicolumn{3}{|c|}{$\mathrm{RD}$} & \multicolumn{4}{|c|}{ Adoption event study } \\
\hline & (1) & $(2)$ & $(3)$ & $(4)$ & $(5)$ & $(6)$ & (7) \\
\hline & OLS & Reduced form & Difference (1) - (2) & OLS & Avg. pre & Avg. post & Difference (4) - (6) \\
\hline \multirow[t]{2}{*}{ (log) Value added } & 0.455 & -0.048 & 0.504 & 2.234 & 0.018 & -0.022 & 2.255 \\
\hline & $(0.025)$ & $(0.026)$ & $(0.032)$ & $(0.027)$ & $(0.033)$ & $(0.054)$ & $(0.060)$ \\
\hline \multirow[t]{2}{*}{$(\log )$ Fixed assets } & 0.689 & -0.092 & 0.781 & 2.360 & -0.023 & -0.268 & 2.628 \\
\hline & $(0.048)$ & $(0.060)$ & $(0.075)$ & $(0.039)$ & $(0.050)$ & $(0.085)$ & $(0.099)$ \\
\hline \multirow[t]{2}{*}{ Investment } & -496.981 & -189.260 & -307.721 & 2962.874 & 1537.507 & 2848.910 & 113.965 \\
\hline & $(562.481)$ & $(1430.889)$ & $(1541.815)$ & $(2642.113)$ & $(2508.064)$ & $(7058.265)$ & $(8066.264)$ \\
\hline \multirow[t]{2}{*}{ (log) Employment } & 0.408 & -0.037 & 0.445 & 2.135 & 0.006 & -0.105 & 2.239 \\
\hline & $(0.014)$ & $(0.010)$ & $(0.017)$ & $(0.024)$ & $(0.024)$ & $(0.042)$ & $(0.049)$ \\
\hline \multirow[t]{2}{*}{ Part-time share } & -0.015 & -0.001 & -0.014 & -0.039 & -0.004 & -0.002 & -0.037 \\
\hline & $(0.003)$ & $(0.005)$ & $(0.005)$ & $(0.002)$ & $(0.003)$ & $(0.005)$ & $(0.005)$ \\
\hline \multirow[t]{2}{*}{ Separation rate } & -0.022 & -0.005 & -0.016 & -0.013 & -0.012 & -0.009 & -0.004 \\
\hline & $(0.003)$ & $(0.006)$ & $(0.006)$ & $(0.002)$ & $(0.008)$ & $(0.008)$ & $(0.008)$ \\
\hline
\end{tabular}

Notes: OLS regressions control for a full set of year, region, and industry indicators, whether the firm is publicly listed, whether the firm is part of a corporate group, and whether the board represents the entire corporate group. In the RD panel, the sample used is the RD sample as defined in Section 2, restricted to firms with between 10 and 50 employees in year $t-1$ which remained above or below the cut-off in years $t-1$ and $t-2$. Column (2) reports estimates of the coefficient $\lambda$ from equation (3). In the adoption panel, the OLS estimate is estimated using the full sample and the adoption event study estimates are estimated using the adoption subsample, as defined in Section 2 , and the comparison groups are as defined in the text. Columns (5) and (6) report averages of the cohort-specific coefficients $\rho^{c, s}$ from equation (5) for the pre- and post-treatment periods, respectively, where all time-periods and cohorts are weighted equally. Standard errors are clustered at the firm-level in all columns. Standard errors of the differences in Columns (3) and (7) are estimated using 500 block bootstrap draws in which the block is taken to be the firm. 